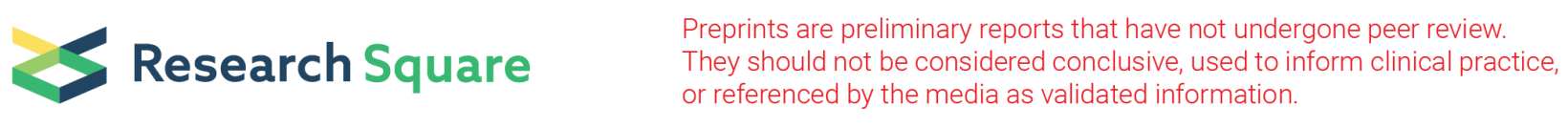

\title{
Impact of Smoking On Surgical Outcomes For Patients Undergoing Cervical Surgery: A Systematic Review And Meta-Analysis
}

\author{
Li-ming Zheng \\ Hubei University of Chinese Medicine \\ Zhi-wen Zhang \\ Hubei Provincial Hospital of Traditional Chinese Medicine \\ Yang Li \\ Hubei University of Chinese Medicine \\ Feng Wen \\ Hubei Provincial Hospital of Traditional Chinese Medicine \\ Wei Wang ( $\sim$ hbzyww@hotmail.com) \\ Hubei Provincial Hospital of Traditional Chinese Medicine
}

\section{Research Article}

Keywords: Smoking, Cervical surgery, Meta-analysis, Outcomes

Posted Date: October 12th, 2021

DOI: https://doi.org/10.21203/rs.3.rs-953208/v1

License: (c) (i) This work is licensed under a Creative Commons Attribution 4.0 International License. Read Full License 


\section{Abstract \\ Objective: To determine whether smoking has adverse effects on outcomes following cervical surgery.}

Methods: We searched PubMed, Embase, Cochrane Library, and Web of Science through 13 July 2021 for cohort and case-control studies that investigated the effect of smoking on outcomes after cervical surgery. Two researchers independently screened the studies and extracted data according to the selection criteria.

Results: The meta-analysis included 43 studies, including 27 case-control studies and 16 cohort studies, with 10020 patients. Pooled estimates showed that smoking was associated with higher rates of overall complications (odds ratio [OR] $=2.00,95 \%$ confidence interval [Cl]: $1.63-2.44, p<0.00001$ ), respiratory complications (OR=3.14, 95\% Cl: 1.94-5.08, $\mathrm{p}<0.00001)$, reoperation (OR=2.22, 95\% Cl: 1.41-3.49, $\mathrm{p}=0.005)$, dysphagia (OR=1.49, 95\% Cl: 1.07-2.07, $\mathrm{p}=0.02)$, wound infection (OR=3.19,95\% Cl: 1.64-6.21, p=0.0006), axial neck pain (OR=1.97, 95\% Cl: 1.25-3.10, p=0.003), and a lower rate of fusion (OR=0.63, 95\% Cl: 0.49-0.81, $\mathrm{p}=0.0003$ ). There were no significant differences between smoking and non-smoking groups in terms of operation time (mean difference [MD] 0.08 , 95\% Cl: -5.54 to $5.71, p=0.98$ ), estimated blood loss ( $M D=-5.31,95 \% \mathrm{Cl}:-148.83$ to $139.22, p=0.94$ ), length of hospital stay ( $M D=1.01,95 \% \mathrm{Cl}:-2.17$ to 4.20 , $\mathrm{p}=0.53)$, Visual Analog Scale-neck pain ( $\mathrm{MD}=-0.19,95 \% \mathrm{Cl}:-1.19$ to $0.81, \mathrm{p}=0.71)$, Visual Analog Scale-arm pain ( $\mathrm{MD}=-0.50,95 \% \mathrm{Cl}:-1.53$ to $0.53, \mathrm{p}=0.34)$, Neck Disability Index (MD=11.46, 95\% Cl: -3.83 to $26.76, p=0.14)$, and Japanese Orthopaedic Association Scores (MD=-1.75, 95\% Cl: -5.27 to $1.78, p=0.33$ ).

Conclusions: Smokers appear to be more likely than non-smokers to suffer higher rates of overall complications, respiratory complications, reoperation, longer hospital stay, dysphagia, wound infection, axial neck pain, and a lower fusion rate following cervical surgery. It is essential to provide timely smoking cessation advice and explanation to patients before selective cervical surgery.

\section{Introduction}

Cigarette smoking is a significant public health concern worldwide. Approximately $20 \%$ of adults in the US currently smoke cigarettes, responsible for up to $20 \%$ of all deaths each year ${ }^{1}$. In some cervical surgeries, more than half of the patients are smokers ${ }^{2-4}$. Smoking is highly detrimental to health and associated with cancer, respiratory disease, and cardiovascular disease ${ }^{5}$. A growing body of evidence shows that smoking is a significant risk factor for adverse surgical outcomes after spine surgery ${ }^{5-8}$.

The relationship between smoking and outcomes of cervical surgery has not been well evaluated. Some studies suggest that smoking may be associated with poorer outcomes after cervical surgery, including lower fusion rates ${ }^{9,10}$. Smoking has been independently linked to higher blood loss ${ }^{11}$, longer lengths of stay 2,11 , and higher reoperation rates ${ }^{12,13}$. There is also an increased risk of perioperative complications, including dysphagia, airway obstruction, nerve palsy, reintubation, axial neck pain, wound infection, deep venous thrombosis, pneumonia, and pseudarthrosis ${ }^{7,11,12,14-17}$. Pain control and functional outcomes have also been shown to be less favorable in smoking patients ${ }^{18,19}$.

Nevertheless, some studies disputed these findings and suggest no relationship between smoking and adverse surgical outcomes after cervical surgery

$18,20,21$. Some researchers even found that the incidence of complications in smokers was lower than that of non-smokers after posterior cervical fusion ${ }^{22}$. We performed the present study to resolve these discrepancies. To the best of our knowledge, there have been no previous systematic reviews and meta-analyses assessing the association between smoking and outcomes of cervical surgery.

\section{Materials And Methods}

\subsection{Literature Search Strategy}

This meta-analysis was performed following the Meta-analysis of Observational Studies in Epidemiology (MOOSE) statement ${ }^{23}$. PubMed, Embase, Cochrane Library, and Web of Science electronic databases were searched from inception to 13 July 2021 using the MeSH terms "smoking," "cervical vertebrae," "surgical procedures, operative," and their corresponding free terms (Appendix S1). The search was restricted to human subjects. In addition, we also review the list of references for retrieved papers and recent reviews.

\subsection{Inclusion And Exclusion Criteria}

The inclusion criteria were as follows: (1) The study design was cohort or case-control; (2) the study population consisted of smokers and non-smokers who underwent cervical surgery; (3) the study compared outcomes, including operating time, pain score, functional score, reoperation rate, length of hospital stay, estimated blood loss, fusion rate, and postoperative complications. Exclusion criteria were as follows: (1) reviews, letters, case reports, systematic reviews, animal studies, non-comparative studies, and studies that were unrelated to our topics; (2) the study did not involve any of the outcomes listed in the inclusion criteria; (3) duplicated publications from the same hospital or research center. For accepted articles covering the same population or subpopulation, the most informative articles or complete studies were used to avoid duplication of information. Disagreements between investigators were resolved by discussion and consensus.

\subsection{Data Extraction}


Data extraction was conducted according to the Preferred Reporting Items for Systematic Reviews and Meta-Analyses (PRISMA) statement, and data were extracted independently by two reviewers and examined by the other authors. Any disagreements were resolved by consensus or discussion with a third reviewer. The following information was extracted from the studies: (1) the general study information (name of the first author, publishing date, country, study design, sample size, age, gender, surgical procedure, follow-up time, and definition of smoking); (2) perioperative parameters, including operative time, estimated blood loss, and length of hospital stay; (3) clinical outcomes, including visual analog scale (VAS) of both neck pain and arm pain, Neck Disability Index (NDI), and Japanese Orthopaedic Association Scores (JOA); (4) complications, fusion rate and reoperation rate; the complications included dysphagia, airway obstruction, nerve palsy, reintubation, axial neck pain, wound infection, deep venous thrombosis, pneumonia, and pseudarthrosis. For continuous outcomes, we extracted the mean and standard deviation, and participant numbers were extracted. For dichotomous outcomes, we extracted the total numbers and the numbers of events of both groups. The data in other forms was recalculated when possible to enable pooled analysis.

\subsection{Methodological Quality}

Two reviewers independently applied the Newcastle-Ottawa Scale (NOS) to evaluate the methodological quality of the included studies ${ }^{24}$. The NOS is a scoring checklist for solving design and implementation issues of a cohort or case-control study, consisting of participant selection, comparability of cases and controls, exposure, and outcomes. If the study is awarded six or more stars, it was considered a high-quality study and was analyzed.

\subsection{Statistical Analysis}

We used Review Manager version 5.4 (The Nordic Cochrane Centre, The Cochrane Collaboration, Copenhagen, Denmark) ${ }^{25}$ to generate forest plots and the funnel plot to determine whether there was a statistical association between the case and control groups and to assess heterogeneity of the included studies. Dichotomous outcomes were expressed as odds ratios (ORs) with 95\% confidence intervals (Cls); continuous outcomes are expressed as the mean differences (MDs). Heterogeneity was quantified evaluated using the chi-square based Cochran's Q statistic ${ }^{26}$ and the $\mathrm{I}^{2}$ statistic, which yields results ranged from 0 to $100 \%\left(I^{2}=0-25 \% \text {, no heterogeneity; } I^{2}=25-50 \% \text {, moderate heterogeneity; } I^{2}=50-75 \% \text {, large heterogeneity; and } I^{2}=75-100 \% \text {, extreme heterogeneity }\right)^{27}$. In cases of substantial heterogeneity, the random-effects model was applied. Otherwise, the fixed-effects model was used. When heterogeneity was present, a 'leave-one-out sensitivity analysis was performed by iteratively removing one study at a time to confirm the source of the heterogeneity. Analysis was then performed without the study to determine if heterogeneity was still present and if so, random-effects modeling was used. For the primary outcomes, subgroup analyses were carried out according to surgical approach (anterior or posterior cervical surgery). Publication bias was assessed using visual inspection of the funnel plot with the Begg ${ }^{28}$ and Egger tests ${ }^{29}$. STATA version 12.0 (StataCorp, College Station, TX) was used for Begg and Egger tests. All statistical tests were two-sided, and p-values of $<0.05$ were considered statistically significant.

\section{Results}

\subsection{Identification of Eligible Studies}

A flowchart of the search and study selection process is shown in Fig. 1. The electronic search identified a total of 352 citations (69 from PubMed, 212 from EMBASE, 20 from the Cochrane Library, and 51 from the Web of Science). After screening titles and abstracts and removal of duplicates, 122 were considered of interest; the full text of these 122 studies was retrieved for detailed evaluation; 79 studies were excluded, and 43 studies were ultimately included in the meta-analysis ${ }^{2-4,7,9-16,18-21,30-56 .}$

\subsection{Characteristics Of Included Studies}

Characteristics of the studies are summarized in Table 1. The 43 independent observational studies included in this meta-analysis were published from 1995 to 2021. These forty-three studies included 10,020 patients, including 3,107 smokers and 6,913 non-smokers. Twenty-seven studies were conducted in the United States and seven in China. The other nine were conducted in India, Japan, Czech Republic, Italy, Korea, Singapore, and Taiwan. Of these, 16 were cohort studies, and 27 were case-controls. Patients in twenty-eight studies underwent anterior cervical surgery ${ }^{57}$, eight underwent posterior cervical surgery $4,12,14,15,36,40,41,48$, and the remaining seven underwent anterior and posterior cervical surgery $2,7,13,21,35,42,50$. 
Table 1

Baseline Characteristics of Included Studies

\begin{tabular}{|c|c|c|c|c|c|c|c|c|c|c|c|}
\hline \multirow{2}{*}{$\begin{array}{l}\text { Series } \\
\text { (Year) }\end{array}$} & \multirow[t]{2}{*}{ Country } & \multirow[t]{2}{*}{ Design } & \multicolumn{2}{|c|}{ Number of patients } & \multirow{2}{*}{$\begin{array}{l}\text { Age } \\
\text { (mean } \pm S D \text {, } \\
\text { year) }\end{array}$} & \multicolumn{2}{|c|}{ Gender,number } & \multirow[t]{2}{*}{ Surgery } & \multirow{2}{*}{$\begin{array}{l}\text { Definition } \\
\text { of } \\
\text { smoking }\end{array}$} & \multirow{2}{*}{$\begin{array}{l}\text { follow-up } \\
\text { (mean } \pm S D)\end{array}$} & \multirow{2}{*}{$\begin{array}{l}\mathrm{N} \\
\mathrm{sc}\end{array}$} \\
\hline & & & Smoker & Nonsmoker & & Male & Female & & & & \\
\hline $\begin{array}{l}\text { Agrillo et } \\
\text { al., } \\
2002[31]\end{array}$ & Italy & $\begin{array}{l}\text { Case- } \\
\text { control }\end{array}$ & 19 & 26 & $49.7(28-77)$ & 26 & 19 & ACDF & $\begin{array}{l}\text { Smoking } \\
\text { history }\end{array}$ & 6 months & 6 \\
\hline $\begin{array}{l}\text { An et al., } \\
\text { 1995[32] }\end{array}$ & USA & Cohort & 34 & 43 & 47.1 & NR & & $\begin{array}{l}\text { Anterior } \\
\text { cervical fusion }\end{array}$ & NR & $12-13$ months & 6 \\
\hline $\begin{array}{l}\text { Badiee et } \\
\text { al., } \\
2021[12]\end{array}$ & USA & $\begin{array}{l}\text { Case- } \\
\text { control }\end{array}$ & 27 & 232 & $63.2 \pm 10.8$ & 129 & 130 & $\begin{array}{l}\text { Posterior } \\
\text { cervical } \\
\text { decompression } \\
\text { and fusion }\end{array}$ & NR & 90 days & 8 \\
\hline $\begin{array}{l}\text { Bergin et } \\
\text { al., } \\
2021 \text { [33] }\end{array}$ & USA & $\begin{array}{l}\text { Case- } \\
\text { control }\end{array}$ & 48 & 278 & 53.8 & 149 & 177 & ACDF & NR & $\begin{array}{l}27.6 \pm 19.0 \\
\text { months }\end{array}$ & 8 \\
\hline $\begin{array}{l}\text { Bose et al., } \\
2001 \text { [20] }\end{array}$ & USA & Cohort & 46 & 60 & $\begin{array}{l}50.12 \pm 11.72(27- \\
80)\end{array}$ & 47 & 59 & ACDF & NR & $>12$ months & 8 \\
\hline
\end{tabular}

\begin{tabular}{|c|c|c|c|c|c|c|c|c|c|c|c|}
\hline $\begin{array}{l}\text { Cerier et al., } \\
\text { 2019[19] }\end{array}$ & USA & Cohort & 23 & 38 & 50.4 & 32 & 29 & ACDF & $\begin{array}{l}\text { Smoking } \\
\text { within } 6 \\
\text { months } \\
\text { before } \\
\text { surgery }\end{array}$ & 6 months & 7 \\
\hline $\begin{array}{l}\text { Chen et al., } \\
2015[34]\end{array}$ & China & $\begin{array}{l}\text { Case- } \\
\text { control }\end{array}$ & 68 & 189 & NR & 138 & 119 & $\begin{array}{l}\text { Single-level } \\
\text { anterior } \\
\text { cervical fusion }\end{array}$ & $\begin{array}{l}\text { Smoking } \\
\text { history }\end{array}$ & 6-24 months & 8 \\
\hline $\begin{array}{l}\text { Dube et al., } \\
2018[35]\end{array}$ & India & $\begin{array}{l}\text { Case- } \\
\text { control }\end{array}$ & 44 & 163 & $3 \mathrm{mo}-86 \mathrm{y}$ & 160 & 47 & $\begin{array}{l}\text { Cervical Spine } \\
\text { Surgery }\end{array}$ & NR & NR & 7 \\
\hline
\end{tabular}

\begin{tabular}{|c|c|c|c|c|c|c|c|c|c|c|c|}
\hline $\begin{array}{l}\text { Eubanks et } \\
\text { al., } \\
2011[36]\end{array}$ & USA & Cohort & 41 & 117 & 61 & 93 & 65 & $\begin{array}{l}\text { Posterior } \\
\text { cervical fusion }\end{array}$ & NR & $\begin{array}{l}14.5(3-72) \\
\text { months }\end{array}$ & 8 \\
\hline $\begin{array}{l}\text { Goldberg et } \\
\text { al., } \\
2002[37]\end{array}$ & USA & Cohort & 30 & 50 & 44.6 & 43 & 37 & ACDF & NR & $4(2-7)$ years & 6 \\
\hline $\begin{array}{l}\text { Groff et al., } \\
2003[38]\end{array}$ & USA & $\begin{array}{l}\text { Case- } \\
\text { control }\end{array}$ & 55 & 89 & 49 & 119 & 25 & $\begin{array}{l}\text { Partial } \\
\text { corpectomy } \\
\text { and fusion }\end{array}$ & $\begin{array}{l}\text { Smoking } \\
\text { within } 3 \\
\text { months } \\
\text { before } \\
\text { surgery }\end{array}$ & $\begin{array}{l}34(>24) \\
\text { months }\end{array}$ & 6 \\
\hline $\begin{array}{l}\text { Hilibrand et } \\
\text { al., 2001[9] }\end{array}$ & USA & Cohort & 55 & 135 & NR & NR & & ACDF & NR & $\begin{array}{l}68(24-183) \\
\text { months }\end{array}$ & 7 \\
\hline $\begin{array}{l}\text { Huang et } \\
\text { al., } \\
2020[16]\end{array}$ & China & $\begin{array}{l}\text { Case- } \\
\text { control }\end{array}$ & 51 & 130 & $52.15 \pm 9.32$ & 104 & 77 & ACDF & NR & $\begin{array}{l}18(12-24) \\
\text { months }\end{array}$ & 8 \\
\hline $\begin{array}{l}\text { Kang et al., } \\
2014[39]\end{array}$ & Korea & $\begin{array}{l}\text { Case- } \\
\text { control }\end{array}$ & 41 & 31 & $47.1 \pm 7.8$ & 50 & 22 & ACDF & $\begin{array}{l}\text { Smoking } \\
\text { history }\end{array}$ & 1 year & 7 \\
\hline
\end{tabular}

NR=not reported; NOS=Newcastle-Ottawa Scale; ACDF=Anterior cervical discectomy and fusion; SD=Standard Deviation; NDI=Neck Disability Index;

VAS=Visual Analog Scale; JOA=Japanese Orthopaedic Association Scores for Assessment of Cervical Myelopathy; EBL=estimated blood loss;

CSF=cerebrospinal fluid; DVT=deep venous thrombosis 


\begin{tabular}{|c|c|c|c|c|c|c|c|c|c|c|c|}
\hline \multirow{2}{*}{$\begin{array}{l}\text { Series } \\
\text { (Year) }\end{array}$} & \multirow[t]{2}{*}{ Country } & \multirow[t]{2}{*}{ Design } & \multicolumn{2}{|c|}{ Number of patients } & \multirow{2}{*}{$\begin{array}{l}\text { Age } \\
\text { (mean } \pm S D, \\
\text { year) }\end{array}$} & \multicolumn{2}{|c|}{ Gender,number } & \multirow[t]{2}{*}{ Surgery } & \multirow{2}{*}{$\begin{array}{l}\text { Definition } \\
\text { of } \\
\text { smoking }\end{array}$} & \multirow{2}{*}{$\begin{array}{l}\text { follow-up } \\
\text { (mean } \pm S D)\end{array}$} & \multirow[t]{2}{*}{$\mathbf{N}$} \\
\hline & & & Smoker & Nonsmoker & & Male & Female & & & & \\
\hline $\begin{array}{l}\text { Kimura et } \\
\text { al., } \\
2018[40]\end{array}$ & Japan & Case- & 39 & 117 & 64 & 108 & 48 & Laminoplasty & $\begin{array}{l}\text { Current } \\
\text { smoking }\end{array}$ & 2 years & 7 \\
\hline
\end{tabular}

\begin{tabular}{|c|c|c|c|c|c|c|c|c|c|c|c|}
\hline $\begin{array}{l}\text { Klement et } \\
\text { al., } \\
2016[41]\end{array}$ & USA & $\begin{array}{l}\text { Case- } \\
\text { control }\end{array}$ & 2 & 27 & 63 & 8 & 21 & $\begin{array}{l}\text { Cervical } \\
\text { laminectomy } \\
\text { and fusion }\end{array}$ & NR & 26.9 months & 8 \\
\hline $\begin{array}{l}\text { Lau et al., } \\
2014[11]\end{array}$ & USA & Cohort & 62 & 70 & NR & 77 & 55 & $\begin{array}{l}\text { Anterior } \\
\text { cervical } \\
\text { corpectomy } \\
\text { and fusion }\end{array}$ & $\begin{array}{l}\text { Smoking } \\
\text { history }\end{array}$ & 1 year & 8 \\
\hline
\end{tabular}

\begin{tabular}{|c|c|c|c|c|c|c|c|c|c|c|c|}
\hline $\begin{array}{l}\text { Lee et al., } \\
2014[42]\end{array}$ & USA & $\begin{array}{l}\text { Case- } \\
\text { control }\end{array}$ & 403 & 955 & $51(20-91)$ & 729 & 629 & $\begin{array}{l}\text { Cervical Spine } \\
\text { surgery }\end{array}$ & NR & $12-168$ months & 7 \\
\hline $\begin{array}{l}\text { Lee et al., } \\
\text { 2015[43] }\end{array}$ & Korea & $\begin{array}{l}\text { Case- } \\
\text { control }\end{array}$ & 333 & 705 & $50(22-89)$ & 514 & 524 & $\begin{array}{l}\text { Anterior } \\
\text { cervical } \\
\text { surgery }\end{array}$ & NR & $\begin{array}{l}50(12-168) \\
\text { months }\end{array}$ & 7 \\
\hline $\begin{array}{l}\text { Liang et al., } \\
\text { 2017[44] }\end{array}$ & China & $\begin{array}{l}\text { Case- } \\
\text { control }\end{array}$ & 59 & 158 & 55.4 & 109 & 108 & $\begin{array}{l}\text { Anterior } \\
\text { cervical } \\
\text { corpectomy } \\
\text { and fusion }\end{array}$ & $\begin{array}{l}\text { Smoking } \\
\text { history }\end{array}$ & NR & 7 \\
\hline $\begin{array}{l}\text { Liu et al., } \\
2019[45]\end{array}$ & China & $\begin{array}{l}\text { Case- } \\
\text { control }\end{array}$ & 39 & 49 & 60.4 & 45 & 43 & ACDF & NR & 1 year & 8 \\
\hline $\begin{array}{l}\text { Luszczyk } \\
\text { et al., } \\
2013[46]\end{array}$ & USA & Cohort & 156 & 417 & NR & NR & & ACDF & $\begin{array}{l}\text { Current } \\
\text { smoking }\end{array}$ & $>24$ months & 6 \\
\hline $\begin{array}{l}\text { Mangan et } \\
\text { al., } \\
2021[47]\end{array}$ & USA & Cohort & 63 & 87 & 53 & 123 & 141 & ACDF & $\begin{array}{l}\text { Smoking } \\
\text { history }\end{array}$ & $\begin{array}{l}\text { 19.8(9-20.6) } \\
\text { months }\end{array}$ & 8 \\
\hline $\begin{array}{l}\text { Martin et } \\
\text { al., } \\
1999[10]\end{array}$ & USA & Cohort & 75 & 214 & NR & 162 & 127 & ACDF & $\begin{array}{l}\text { Smoking } \\
\text { history }\end{array}$ & $\begin{array}{l}33(24-51) \\
\text { months }\end{array}$ & 8 \\
\hline
\end{tabular}

NR=not reported; NOS=Newcastle-Ottawa Scale; ACDF=Anterior cervical discectomy and fusion; SD=Standard Deviation; NDI=Neck Disability Index; VAS=Visual Analog Scale; JOA=Japanese Orthopaedic Association Scores for Assessment of Cervical Myelopathy; EBL=estimated blood loss;

CSF=cerebrospinal fluid; DVT=deep venous thrombosis 


\begin{tabular}{|c|c|c|c|c|c|c|c|c|c|c|c|}
\hline \multirow{2}{*}{$\begin{array}{l}\text { Series } \\
\text { (Year) }\end{array}$} & \multirow[t]{2}{*}{ Country } & \multirow[t]{2}{*}{ Design } & \multicolumn{2}{|c|}{ Number of patients } & \multirow{2}{*}{$\begin{array}{l}\text { Age } \\
\text { (mean } \pm S D, \\
\text { year) }\end{array}$} & \multicolumn{2}{|c|}{ Gender,number } & \multirow[t]{2}{*}{ Surgery } & \multirow{2}{*}{$\begin{array}{l}\text { Definition } \\
\text { of } \\
\text { smoking }\end{array}$} & \multirow{2}{*}{$\begin{array}{l}\text { follow-up } \\
\text { (meantSD) }\end{array}$} & \multirow{2}{*}{$\begin{array}{l}\mathrm{N} \\
\mathrm{sc}\end{array}$} \\
\hline & & & Smoker & Nonsmoker & & Male & Female & & & & \\
\hline $\begin{array}{l}\text { Nakashima } \\
\text { et al., } \\
2013[48]\end{array}$ & Japan & Case- & 55 & 109 & $44.9(14-90)$ & 142 & 22 & $\begin{array}{l}\text { Posterior } \\
\text { cervical } \\
\text { surgery }\end{array}$ & $\begin{array}{l}\text { Smoking } \\
\text { history }\end{array}$ & 59.9 months & 7 \\
\hline & & control & & & & & & & & & \\
\hline $\begin{array}{l}\text { Pahys et } \\
\text { al., } \\
2013[14]\end{array}$ & USA & $\begin{array}{l}\text { Case- } \\
\text { contorl }\end{array}$ & 126 & 357 & 53.7 & 268 & 215 & $\begin{array}{l}\text { Posterior } \\
\text { cervical spine } \\
\text { surgery }\end{array}$ & $\begin{array}{l}\text { Smoking } \\
\text { history }\end{array}$ & $>3$ months & 8 \\
\hline $\begin{array}{l}\text { Patel et al., } \\
\text { 2019[49] }\end{array}$ & USA & Cohort & 25 & 167 & 48.7 & 115 & 77 & ACDF & NR & 6 months & 8 \\
\hline $\begin{array}{l}\text { Plano et } \\
\text { al., } \\
2019[50]\end{array}$ & USA & $\begin{array}{l}\text { Case- } \\
\text { control }\end{array}$ & 128 & 175 & $\begin{array}{l}57.7 \pm 12.6(27- \\
86)\end{array}$ & 200 & 103 & $\begin{array}{l}\text { Cervical Spine } \\
\text { surgery }\end{array}$ & NR & $\begin{array}{l}75.35 \pm 27.1(16- \\
126) \text { months }\end{array}$ & 7 \\
\hline $\begin{array}{l}\text { Reinard et } \\
\text { al., 2016[2] }\end{array}$ & USA & $\begin{array}{l}\text { Case- } \\
\text { control }\end{array}$ & 47 & 30 & $\begin{array}{l}55.1 \pm 12.88(20- \\
86)\end{array}$ & 50 & 27 & $\begin{array}{l}\text { Combined } \\
\text { anterior- } \\
\text { posterior } \\
\\
\text { cervical spinal } \\
\text { fusions }\end{array}$ & $\begin{array}{l}\text { Smoking } \\
\text { history }\end{array}$ & NR & 8 \\
\hline $\begin{array}{l}\text { Ren et al., } \\
2020[51]\end{array}$ & China & $\begin{array}{l}\text { Case- } \\
\text { control }\end{array}$ & 106 & 189 & 59.7 & 139 & 156 & ACDF & NR & 6 months & 8 \\
\hline $\begin{array}{l}\text { Riederman } \\
\text { et al., } \\
\text { 2017[7] }\end{array}$ & USA & $\begin{array}{l}\text { Case- } \\
\text { control }\end{array}$ & 36 & 164 & $52.4(28-87)$ & 112 & 88 & ACDF & $\begin{array}{l}\text { Smoking } \\
\text { history }\end{array}$ & NR & 7 \\
\hline $\begin{array}{l}\text { Sagi et al., } \\
2002[53]\end{array}$ & USA & $\begin{array}{l}\text { Case- } \\
\text { control }\end{array}$ & 127 & 184 & 47 & 169 & 142 & $\begin{array}{l}\text { Anterior } \\
\text { cervical } \\
\text { surgery }\end{array}$ & NR & NR & 7 \\
\hline $\begin{array}{l}\text { Schnee et } \\
\text { al., } \\
1997[30]\end{array}$ & USA & $\begin{array}{l}\text { Case- } \\
\text { control }\end{array}$ & 66 & 78 & $48.1(27-82)$ & 71 & 73 & $\begin{array}{l}\text { Anterior } \\
\text { cervical fusion }\end{array}$ & NR & $\begin{array}{l}8.1(2.7-34.2) \\
\text { months }\end{array}$ & 6 \\
\hline $\begin{array}{l}\text { Siemionow } \\
\text { et al., } \\
2014[7]\end{array}$ & USA & $\begin{array}{l}\text { Case- } \\
\text { control }\end{array}$ & 16 & 19 & $60(37-82)$ & 21 & 14 & $\begin{array}{l}\text { Combined } \\
\text { anterior- } \\
\text { posterior } \\
\text { cervical spinal } \\
\text { fusions }\end{array}$ & NR & $>12$ months & 6 \\
\hline $\begin{array}{l}\text { Suchomel } \\
\text { et al., } \\
2004[54]\end{array}$ & $\begin{array}{l}\text { Czech } \\
\text { Republic }\end{array}$ & Cohort & 48 & 31 & $47.8(37-73)$ & 49 & 30 & ACDF & $\begin{array}{l}\text { Smoking } \\
\text { history }\end{array}$ & $\begin{array}{l}39.4(24-48) \\
\text { months }\end{array}$ & 7 \\
\hline
\end{tabular}

NR=not reported; NOS=Newcastle-Ottawa Scale; ACDF=Anterior cervical discectomy and fusion; SD=Standard Deviation; NDI=Neck Disability Index; VAS=Visual Analog Scale; JOA=Japanese Orthopaedic Association Scores for Assessment of Cervical Myelopathy; EBL=estimated blood loss;

CSF=cerebrospinal fluid; DVT=deep venous thrombosis 


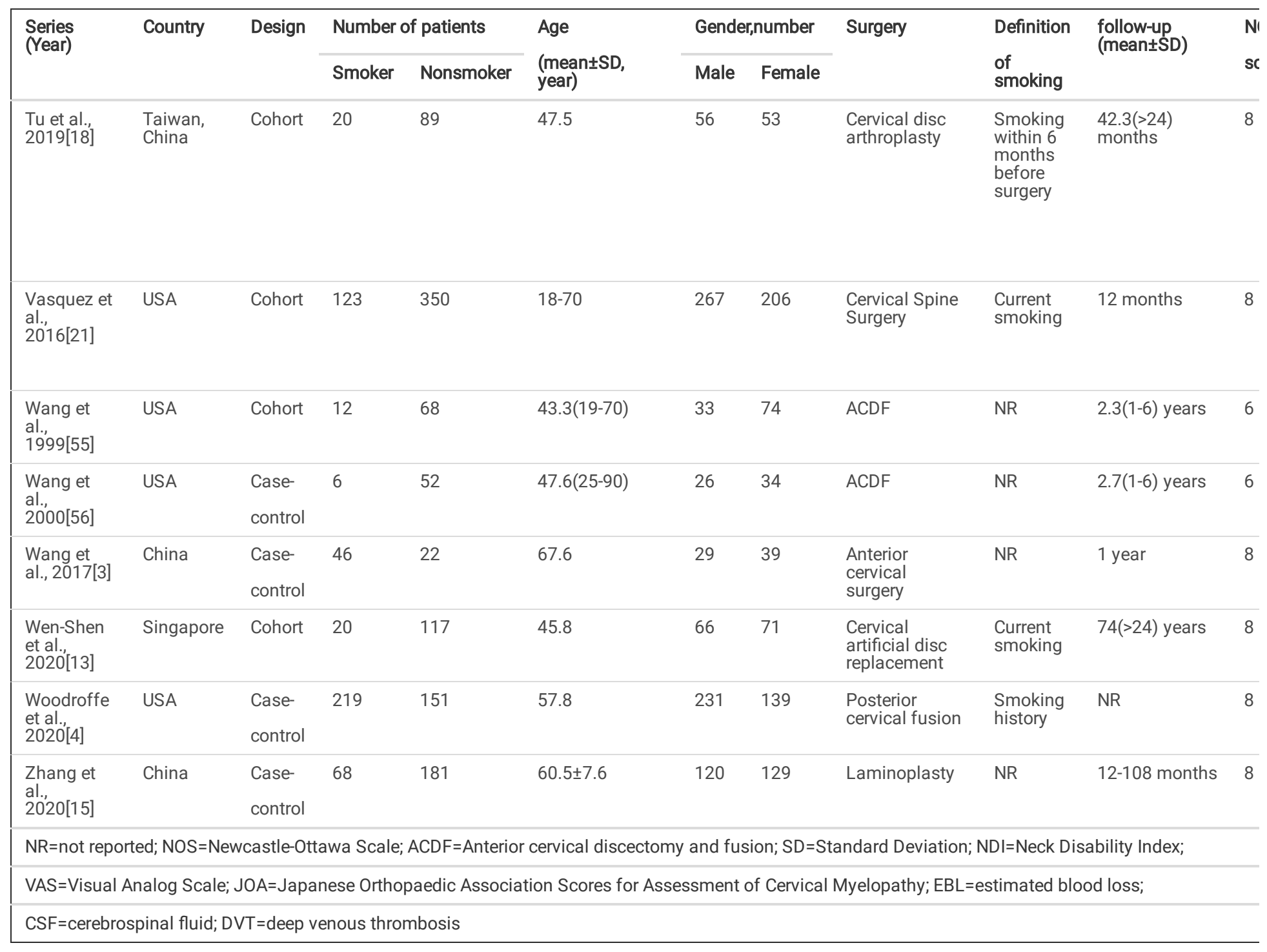

\subsection{Quality Of Included Studies}

Because all included studies were cohort studies or case-control studies, the quality of each study was evaluated using the NOS (maximum of nine stars) in three categories: selection, comparability, and exposure or outcomes. According to the NOS scale, all included studies were considered to be of high-quality: 21 were awarded eight stars, 13 were awarded seven stars, and 9 were awarded six stars (Table 2). 
Table 2

Quality Assessment of Included Studies According to Newcastle-Ottawa Scale

\begin{tabular}{|c|c|c|c|c|}
\hline Study & Selection & Comparability & Outcome/Exposure & Total \\
\hline Agrillo et al., 2002 & वस्पा & & 吅 & 6 \\
\hline An et al., 1995 & प्रा & & $\mathrm{Qut}$ & 6 \\
\hline Badiee et al., 2021 & स्या & प्र & प्र & 8 \\
\hline Bergin et al., 2021 & 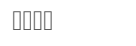 & 吅 & प्र & 8 \\
\hline Bose et al., 2001 & प्रा & $\mathrm{Q}$ & 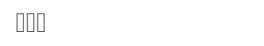 & 8 \\
\hline Cerier et al., 2019 & प्रा & प & प्रा & 7 \\
\hline Chen et al., 2015 & वस्पा & $\mathrm{Qu}$ & प्र & 8 \\
\hline Dube et al., 2018 & 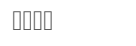 & $\mathrm{Qu}$ & ? & 7 \\
\hline Eubanks et al., 2011 & प्रा & 吅 & $\mathrm{Qut}$ & 8 \\
\hline Goldberg et al., 2002 & प्रा & & प्रा & 6 \\
\hline Groff et al., 2003 & ०स्पा & प & प & 6 \\
\hline Hilibrand et al., 2001 & प्रा & 口 & प्या & 7 \\
\hline Huang et al., 2020 & 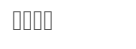 & 吅 & प्र & 8 \\
\hline Kang et al., 2014 & प्राप्रा & प्र & प & 7 \\
\hline Kimura et al., 2018 & स्सा & प्रा & प & 7 \\
\hline Klement et al., 2016 & वस्पा & प्र & प्र & 8 \\
\hline Lau et al., 2014 & 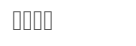 & प & 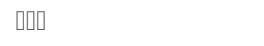 & 8 \\
\hline Lee et al., 2014 & वस्पा & 吅 & प & 7 \\
\hline Lee et al., 2015 & वस्पा & 吅 & प & 7 \\
\hline Liang et al., 2017 & प्या & 吅 & प & 7 \\
\hline Liu et al., 2019 & प्या & 吅 & 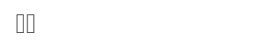 & 8 \\
\hline Luszczyk et al., 2013 & प्रा & & $\mathrm{Quस}$ & 6 \\
\hline Mangan et al., 2021 & प्रा & $\mathrm{Qu}$ & प्रा & 8 \\
\hline Martin et al., 1999 & वस्पा & प & प्रा & 8 \\
\hline Nakashima et al., 2013 & 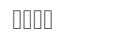 & 吅 & प & 7 \\
\hline Pahys et al., 2013 & 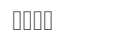 & 吅 & प्र & 8 \\
\hline Patel et al., 2019 & प्रा & 吅 & $\mathrm{Quा}$ & 8 \\
\hline Plano et al., 2019 & 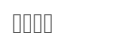 & 口 & प्र & 7 \\
\hline Reinard et al., 2016 & 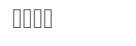 & 吅 & प्र & 8 \\
\hline Ren et al., 2020 & वस्पा & 吅 & प्र & 8 \\
\hline Riederman et al., 2017 & वस्पा & प & प्र & 7 \\
\hline Sagi et al., 2002 & वस्पा & प & प्र & 7 \\
\hline Schnee et al., 1997 & स्सा & & प्र & 6 \\
\hline Siemionow et al., 2014 & प्या & & 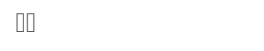 & 6 \\
\hline Suchomel et al., 2004 & 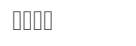 & & 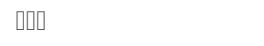 & 7 \\
\hline Tu et al., 2019 & प्रा & 吅 & 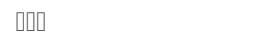 & 8 \\
\hline Vasquez et al., 2016 & प्रा & 吅 & 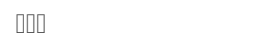 & 8 \\
\hline Wang et al., 1999 & प्रा & & प्रा & 6 \\
\hline Wang et al., 2000 & स्या & & प्र & 6 \\
\hline Wang et al., 2017 & 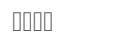 & $\mathrm{Qu}$ & $\mathrm{Qu}$ & 8 \\
\hline Wen-Shen et al., 2020 & प्रा & $\mathrm{Qu}$ & प्रा & 8 \\
\hline
\end{tabular}

Page 8/23 


\begin{tabular}{|c|c|c|c|c|}
\hline Study & Selection & Comparability & Outcome/Exposure & Total \\
\hline Woodroffe et al., 2020 & प्राप्रा & प्र & प्र & 8 \\
\hline Zhang et al., 2020 & पराप & पा & प्रा & 8 \\
\hline
\end{tabular}

\subsection{Meta-analysis}

\subsubsection{Overall Complications}

The primary outcomes in our meta-analysis were complications, including dysphagia, airway obstruction, nerve palsy, reintubation, axial neck pain, wound infection, deep venous thrombosis, pneumonia, deltoid weakness, tracheobronchitis, and pseudarthrosis. At least one postoperative complication was reported in 20 studies 2,3,11,12,14,16,18,20,21,30,34-36,39,41,43,44,48,52,53. Significant heterogeneity was observed, and the random-effects model was used ( $\left.\right|^{2}=52 \%$, $\left.p=0.003\right)$. The meta-analysis revealed that the incidence of postoperative complications in smokers was significantly higher than that of non-smokers (OR=1.88, $95 \% \mathrm{Cl}$ : $1.46-2.76, p<0.0001)$. Because of the heterogeneity $\left(I^{2}=52 \%\right)$, a sensitivity analysis was performed. The study of Reinard et al. ${ }^{2}$ excluded patients with a recombinant human bone morphogenetic protein associated with dysphagia after cervical surgery ${ }^{58}$. It may affect the incidence of postoperative dysphagia. Excluding this paper reduced $\mathrm{I}^{2}$ to $47 \%$ (Fig. 2). Re-analysis using a fixed-effects model revealed that, compared with non-smokers, smokers had a higher incidence of complications (OR=2.00, 95\% Cl: 1.63-2.44, $\mathrm{p}<0.00001)$.

\subsubsection{Respiratory Complications}

Six studies reported the postoperative incidence of respiratory complications, including dyspnea, reintubation, airway obstruction, pneumonia, and tracheotomy $7,11,20,35,48,53$. There was significant heterogeneity $\left(I^{2}=54 \%, p=0.06\right)$; therefore, the random-effects model was used. Pooling of the results demonstrated that the incidence of respiratory complications in smokers was significantly higher than that of non-smokers (OR=2.34, 95\% Cl: $1.04-5.26$, $\mathrm{p}=0.04$ ). After performing sensitivity analysis and removing the study by Sagi et al. ${ }^{53}$ a higher proportion of patients who had exposure of $\mathrm{C} 4$ or above compared with other studies, the heterogeneity was reduced to $37 \%$ (Fig. 3). Fixed-effects modeling showed that the incidence of respiratory complications in smokers was significantly higher than that of non-smokers (OR=3.14, 95\% Cl: 1.94-5.08, $p<0.00001)$.

\subsubsection{Reoperation}

The number of patients who underwent reoperation was provided in eight studies $4,11-13,20,42,47,50$. Significant heterogeneity was observed, and a randomeffects model was used $\left(1^{2}=58 \%, p=0.02\right)$. Pooling of the results demonstrated that the incidence of reoperation in the smoking group was significantly higher than that of the non-smoking group $(\mathrm{OR}=1.94,95 \% \mathrm{Cl}: 1.0-3.80, \mathrm{p}=0.05)$. When performing statistical analysis of Mangan et al. ${ }^{47}$, we defined the sum of current and former smokers as the total number of smokers. We then removed Mangan et al., performed a sensitivity analysis, and found that heterogeneity was reduced to $39 \%$ (Fig. 4). Re-analysis using a fixed-effects model revealed that the incidence of reoperation in the smoking group was significantly higher than that of the non-smoking group $(\mathrm{OR}=2.22,95 \% \mathrm{Cl}: 1.41-3.49, \mathrm{p}=0.005)$.

\subsubsection{Fusion Rate}

Sixteen studies reported the fusion rate or the incidence of pseudarthrosis and nonunion ${ }^{9-11,19,20,31-33,37,38,46,47,51,54-56}$. No significant heterogeneity was observed, and a fixed-effects model was used $\left(I^{2}=16 \%, p=0.0003\right)$. Pooling of the results demonstrated that the fusion rate of smokers after cervical surgery was significantly lower than that of non-smokers (OR=0.63, 95\% Cl: 0.49-0.81, p=0.0003; Fig. 5).

\subsubsection{Dysphagia}

Seven studies reported the postoperative incidence of dysphagia $2,3,16,18,20,34,52$. No significant heterogeneity was observed, and a fixed-effects model was used $\left(I^{2}=47 \%, p=0.07\right)$. Pooling of the results demonstrated that the incidence of dysphagia in the smoking group was significantly higher than that of the nonsmoking group (OR=1.49, 95\% Cl: 1.07-2.07, p=0.02; Fig. 6).

\subsubsection{Wound Infection}

Seven studies reported the postoperative incidence of wound infection 7,11,12,14,18,30,36. No significant heterogeneity was observed, and a fixed-effects model was used $\left(I^{2}=17 \%, p=0.30\right)$. Pooling of the results demonstrated that the incidence of wound infection in the smoking group was significantly higher than that of the non-smoking group (OR=3.19, 95\% Cl: 1.64-6.21, p=0.0006; Fig. 7).

\subsubsection{Axial Neck Pain}


Three studies reported the postoperative incidence of axial neck pain ${ }^{15,40,45}$. Significant heterogeneity was observed, and a random-effects model was used $\left(I^{2}=64 \%, p=0.06\right)$. Pooling of the results shows no significant difference in the incidence of axial neck pain after cervical surgery between smokers and nonsmokers. (OR=1.54, 95\% Cl: 0.75-3.16, p=0.24). After performing sensitivity analysis and removing the study by Liu et al. ${ }^{45}$ the only article on anterior cervical surgery, the heterogeneity was reduced to $39 \%$ (Fig. 8). Fixed-effects modeling revealed that the incidence of axial neck pain in the smoking group was significantly higher than that of the non-smoking group (OR=1.97, 95\% Cl: $1.25-3.10, p=0.003)$.

\subsubsection{Operation Time}

The operation time was provided in two studies ${ }^{21,49}$. No significant heterogeneity was observed, and a fixed-effects model was used $\left(I^{2}=0, p=0.96\right)$. Pooling of the results revealed no significant difference in operation time after cervical surgery between smokers and non-smokers $(\mathrm{MD}=0.08,95 \% \mathrm{Cl}:-5.54$ to 5.71 , $\mathrm{p}=0.98$; Fig. 9).

\subsubsection{Estimated Blood Loss}

The estimated blood loss was provided in three studies $2,11,49$. Significant heterogeneity was observed, and a random-effects model was used $\left(I^{2}=66 \%\right.$, $\mathrm{p}=0.05)$. Pooling of the results revealed no significant difference in estimated blood loss after cervical surgery between smokers and non-smokers $(M D=-5.31$, $95 \% \mathrm{Cl}:-148.83$ to 139.22 , p=0.94; Fig. 10). After performing leave-one-out sensitivity analysis, the heterogeneity did not change substantially and remained significant.

\subsubsection{Length Of Hospital Stay}

The length of hospital stay was provided in four studies $2,11,21,49$. Significant heterogeneity was observed, and a random-effects model was used $\left(I^{2}=88 \%\right.$, $\mathrm{p}<0.0001)$. Pooling of the results revealed no significant difference in length of hospital stay after cervical surgery between smokers and non-smokers $(M D=1.01,95 \% \mathrm{Cl}:-2.17$ to $4.20, p=0.53$; Fig. 11$)$. After performing leave-one-out sensitivity analysis, the heterogeneity did not change substantially and remained significant.

\subsubsection{VAS: Neck Pain}

VAS-neck pain was reported in two studies ${ }^{18,49}$. No significant heterogeneity was observed, and a fixed-effects model was used $\left(I^{2}=0, p=0.53\right)$. Pooling of the results revealed no significant difference in VAS-neck pain after cervical surgery between smokers and non-smokers $(M D=-0.19,95 \% C l:-1.19$ to $0.81, p=0.71$; Fig. 12).

\subsubsection{VAS: Arm Pain}

VAS-arm pain was reported in two studies ${ }^{18,49}$. No significant heterogeneity was observed, and a fixed-effects model was used $\left(I^{2}=0, p=1.00\right)$. Pooling of the results revealed no significant difference in VAS-arm pain after cervical surgery between smokers and non-smokers $(\mathrm{MD}=-0.50,95 \% \mathrm{Cl}:-1.53$ to $0.53, \mathrm{p}=0.34$; Fig. 13).

\subsubsection{NDI}

NDI was reported in four studies $18,19,21,49$. Significant heterogeneity was observed, and a random-effects model was used $\left({ }^{2}=96 \%, p<0.00001\right)$. Pooling of the results revealed no significant difference in NDI after cervical surgery between smokers and non-smokers (MD=11.46, 95\% Cl: -3.83 to 26.76 , $p=0.14$; Fig. 14 ). After performing leave-one-out sensitivity analysis, the heterogeneity did not change substantially and remained significant.

\subsubsection{JOA}

JOA was reported in two studies ${ }^{18,21}$. Significant heterogeneity was observed, and a random-effects model was used $\left(I^{2}=89 \%, p=0.002\right)$. Pooling of the results revealed no significant difference in JOA after cervical surgery between smokers and non-smokers (MD=-1.75, 95\% Cl: -5.27 to 1.78, p=0.33; Fig. 15). After performing leave-one-out sensitivity analysis, the heterogeneity did not change substantially and remained significant.

\subsection{Subgroup Analysis}

For primary outcomes, we conducted subgroup analysis based on the type of surgical approach. In patients who underwent anterior cervical surgery, smoking had adverse effects on overall complications ( $\mathrm{OR}=1.71,95 \% \mathrm{Cl}: 1.35-2.16, \mathrm{p}<0.00001)$, respiratory complications $(\mathrm{OR}=3.81,95 \% \mathrm{Cl}$ : $1.81-8.05, \mathrm{p}=0.0004)$, 
fusion rate $(\mathrm{OR}=0.63,95 \% \mathrm{Cl}: 0.49-0.81, \mathrm{p}=0.0003)$, dysphagia $(\mathrm{OR}=1.70,95 \% \mathrm{Cl}: 1.19-2.42, \mathrm{p}=0.003)$. For outcomes including reoperation (OR=0.65, 95\% $\mathrm{Cl}$ : $0.32-1.31, p=0.23)$, wound infection ( $O R=1.37,95 \% \mathrm{Cl}$ : 0.52-3.62, $\mathrm{p}=0.52)$, and axial neck pain ( $\mathrm{OR}=0.68,95 \% \mathrm{Cl}$ : 0.26-1.78, $\mathrm{p}=0.43)$, smoking had no effect.

In patients who underwent posterior cervical surgery, smoking had adverse effects on overall complications (OR=4.88, 95\% $\mathrm{Cl}$ : $2.72-8.74, \mathrm{p}<0.00001)$, wound infection ( $\mathrm{OR}=8.95,95 \% \mathrm{Cl}$ : 3.23-24.76, $\mathrm{p}<0.0001)$, and axial neck pain ( $\mathrm{OR}=1.97,95 \% \mathrm{Cl}$ : 1.25-3.10, $\mathrm{p}=0.003)$. For reoperation (OR=3.65, 95\% Cl: 1.15-11.58, $p=0.03)$, smoking had no effect.

\subsection{Publication Bias}

Begg rank correlation test and Egger linear regression test indicated no evidence of significant publication bias among the included studies (Egger $\mathrm{p}=0.266$; Begg p=0.266; Fig. 17, Fig. 18), and funnel plots showed a symmetric distribution, indicating no publication bias. (Fig. 16).

\section{Discussion}

The major purpose of the present meta-analysis was to determine whether smoking has adverse effects on surgical outcomes after cervical surgery. Our results suggest that smoking is associated with a higher risk of reoperation and postoperative complications, including dysphagia, axial neck pain, and wound infection. Smokers had a higher incidence of overall complications and respiratory complications and a lower fusion rate. There were no significant differences among smokers and non-smokers concerning outcomes, including operation time, estimated blood loss, length of hospital stays, VAS-neck pain, VAS-arm pain, NDI, or JOA. Our results suggest that smoking might have adverse effects on surgical outcomes in patients who undergo cervical surgery.

Complications were the primary outcome to evaluate the safety of cervical surgery among smoking patients. Siemionow et al. conducted a study of 35 patients undergoing anterior and posterior cervical decompression and fusion and reported that smoking appeared to be the most critical factor related to perioperative complications; the risks for at least one perioperative complication were $50 \%$ and $31.6 \%$ for smokers and non-smokers, respectively ${ }^{7}$. Lau et al. studied 160 patients undergoing anterior cervical corpectomy and found that smoking patients had longer hospital stays, more bleeding, a higher rate of pseudarthrosis, and more complications at 30 days than non-smoking patients ${ }^{11}$. By contrast, Fehlings et al. analyzed data from the AOSpine North America Cervical Spondylotic Myelopathy Study and concluded that perioperative complications were not associated with smoking status ${ }^{59}$. Medvedev et al. reported that the complication rates in smoking and non-smoking patients of $23.5 \%$ and $39.8 \%(p<0.0001)$, respectively ${ }^{22}$. Our pooled data showed that smoking was associated with increased postoperative complications, including dysphagia, airway obstruction, nerve palsy, reintubation, axial neck pain, wound infection, deep venous thrombosis, pneumonia, and pseudarthrosis.

We assessed perioperative outcomes, including operation time, estimated blood loss, and length of hospital stay in our meta-analysis and failed to find any significant difference between the smoking and non-smoking groups. As measured by NDI, JOA, and VAS, functional recovery was similar between the two groups. This finding indicates that cervical surgery might offer similar functional outcomes in smoking patients. However, the relatively small sample size limited the generalizability of this conclusion.

After cervical surgery, smokers had a higher reoperation rate and a lower fusion rate. In this meta-analysis, given that functional improvement between the groups was similar, it is possible that higher reoperation rates were directly related to the higher incidence of complications in smoking patients, including wound infection, respiratory complications, and pseudarthrosis. Through subgroup analysis, we found that smoking did not influence reoperation rates for patients undergoing anterior cervical surgery, while higher rates were found for smoking patients undergoing posterior cervical surgery. Due to limited data, we did not perform a subgroup analysis based on the type of surgical procedure.

There are several potential explanations for the observed association between smoking and adverse effects on the surgical outcomes for patients after cervical surgery. First, cigarette smoke products have been shown to inhibit prostacyclin production, a potent vasodilator, and an inhibitor of platelet aggregation. This effect can lead to impaired blood flow and increased blood viscosity, resulting in impaired blood supply $60-64$, leading to decreased angiogenesis and epithelialization ${ }^{65}$. Moreover, inhibition of revascularization by nicotine was observed in a rabbit study, and this mechanism may retard cellular metabolism and promote tissue degeneration ${ }^{66}$.

Second, at the cellular level, nicotine has been shown to inhibit proliferation, differentiation, and collagen synthesis in osteoblasts ${ }^{67}$, which was the primary determinant of the tensile strength of a surgical wound ${ }^{68}$. Free radicals produced by burning cigarettes have been associated with cell membrane destabilization, impair osteoblasts' mitochondrial oxidative function and lead to local tissue hypoxia $60,69-73$.

Third, it is well-documented that smoking harms bone physiology, resulting in decreased bone mineral density, impaired bone metabolism, and accelerated osteoporosis, with resulting lower fusion rates ${ }^{74}$. Animal and in vitro studies found that nicotine impaired bone healing, retarded bone formation and growth, and decreased graft biomechanical properties ${ }^{75,76}$.

Finally, cigarette smoke contains many toxic ingredients. Nicotine, tar, and other components irritate mucous membranes of the respiratory tract and cause cilia of bronchial epithelial cells to become shorter and irregular, which can hinder the movement of ciliary bodies, reduce local resistance, weaken phagocytosis and sterilization functions of alveolar phagocytes, leading to bronchospasm and increased airway resistance ${ }^{77}$. For these reasons, smokers are susceptible to respiratory complications after cervical surgery. In addition, carbon monoxide combines with hemoglobin, reducing the oxygen-carrying capacity of the blood, and hydrogen cyanide inhibits cytochrome c, which leads to inhibition of aerobic metabolism ${ }^{78}$. 
To the best of our knowledge, our meta-analysis, on the basis of 16 cohort studies and 27 case-control studies, is the first, also the largest and most comprehensive assessment to investigate the association between smoking and outcomes of cervical surgery. The main strength of this systematic review and meta-analysis is the thorough literature search, careful study selection with strict inclusion criteria, and comprehensive assessment of methodological quality of included studies using the NOS, which is the accepted standard currently. In addition, we performed subgroup analysis according to the surgical approach for the primary outcomes. Although we found significant heterogeneity in several outcomes among the included studies, the sensitivity analysis showed no significant change, suggesting that the pooled estimate in our study was stable. Finally, publication bias was assessed by visually inspecting funnel plots and quantitatively evaluated using Begg and Egger linear regression tests.

This systematic review and meta-analysis has several limitations that are worthy of comment. First, studies included in our review span over two decades (1995 to 2021), during which advancements in cervical surgery techniques might have improved outcomes. Despite this, point estimates for earlier and more recent studies were similar. Second, all of the included studies were retrospective observational trials rather than randomized controlled trials. The inherent nature of observational trials may be associated with selective bias, which might have influences on our results. Third, in most studies, the definition of smoking was not standardized, and self-reporting introduces recall bias or response bias because non-smokers may be current or former smokers. Therefore, the true impact of smoking may be larger than we have reported here. Moreover, the definition of complications was not uniform and might introduce an additional source of bias. Fourth, since most of the information collected was not used to answer specific questions, all characteristics of smoker and nonsmoker cohorts such as age, sex, BMI, ethnic group, indications for surgery, and comorbidities were not necessarily consistently matched, leaving some possible residual confusion. What's more, due to the limited number of articles, we did not compare the various types of cervical surgeries in detail. Nevertheless, we attempted to perform a subgroup analysis for the primary outcomes via the surgical approach. Finally, we do not know how investigators confirmed that their patients did not smoke before or after surgery or even if they quitted smoking before surgery, which may have impacted the evaluated results.

One study analyzed the pack-year history and found that, after lumbar surgery, nicotine exposure was associated with an increased risk of disease, and there was a dose-response trend; but this trend was not significant ${ }^{79}$. On the contrary, another study did not support this view and found that after anterior cervical discectomy and fusion, pack-years were not significantly associated with greater odds of developing any one complication or any major complication ${ }^{80}$. This may be related to differences in the number, characteristics, surgical sites, and follow-up time of the population included in the study. Therefore, there is an urgent need for further high-quality studies that are sufficiently prepared and designed with sufficient detail to adjust for multiple confounders and allow exploration of dose-response relationships.

Some researchers reported that preoperative smoking cessation might improve surgery outcomes and could lower medical costs by decreasing postoperative complications and length of post-surgical hospital stay among smokers ${ }^{11,81}$. Sørensen et al. performed a meta-analysis and found that smoking cessation reduced the risk of surgical site infection in plastic and general surgery patients by more than half ${ }^{82}$. Andersen et al. found that quitting smoking significantly increased the rate of fusion after spinal surgery compared to those who continued to smoke, bringing it close to the level of non-smokers ${ }^{83}$. This may be related to the rapid recovery of tissue local oxygenation and metabolism after smoking cessation ${ }^{84}$. Therefore, it is theoretically necessary to quit smoking before elective surgery.

Nevertheless, the optimal timing to quit smoking remains a matter of considerable debate. A study showed that quitting smoking 1 to 2 months before surgery can significantly reduce the perioperative risk ${ }^{79}$. Another report indicated that smoking cessation must be at least 4 weeks before surgery to be effective ${ }^{12}$. Thus, exploring the optimal timing to quit smoking before the operation should determine future efforts.

\section{Conclusions}

We found significant differences in overall complications, respiratory complications, reoperation rate, fusion rate, dysphagia, wound infection, and axial neck pain between smokers and non-smokers after cervical surgery. Our results suggest that smoking increases the rate of adverse outcomes after neck surgeries. It is crucial to provide timely smoking cessation advice and explanation to patients before selective cervical surgery.

\section{Abbreviations}

Cls=confidence intervals; ORs=odds ratios; $\mathbf{N R = n o t ~ r e p o r t e d ; ~ N O S = N e w c a s t l e - O t t a w a ~ S c a l e ; ~} \mathbf{A C D F = A n t e r i o r ~ c e r v i c a l ~ d i s c e c t o m y ~ a n d ~ f u s i o n ; ~} \mathbf{S D}=\mathrm{Standard}$ Deviation; NDI=Neck Disability Index; JOA=Japanese Orthopaedic Association Scores; VAS=Visual Analog Scale; EBL=estimated blood loss; CSF=cerebrospinal fluid; DVT=deep venous thrombosis.

\section{Declarations}

\section{Acknowledgments}

This work was supported by the Natural Science Foundation of Hubei Province [Grant No. 2019CFC901]

\section{Authors' contributions}

Li-ming Zheng: Conceptualization, Methodology, Formal analysis, Investigation, Writing - original draft

Zhi-wen Zhang: Formal analysis, Investigation, Writing - original draft 
Yang Li: Formal analysis, Writing - original draft

Feng Wen: Formal analysis, Writing - original draft

Wang Wei: Writing-review \& editing, Supervision.

\section{References}

1. Simmons, V. N., Litvin, E. B., Unrod, M. \& Brandon, T. H. Oncology healthcare providers' implementation of the $5 A^{\prime}$ s model of brief intervention for smoking cessation: patients' perceptions. Patient Educ Couns, 86, 414-419 https://doi.org/10.1016/j.pec.2011.06.016 (2012).

2. Reinard, K. A. et al. A cohort study of the morbidity of combined anterior-posterior cervical spinal fusions: incidence and predictors of postoperative dysphagia. Eur Spine J, 25, 2068-2077 https://doi.org/10.1007/s00586-016-4429-0 (2016).

3. Wang, T. et al. Factors predicting dysphagia after anterior cervical surgery: A multicenter retrospective study for 2 years of follow-up. Med. (Baltim), 96 , e7916 https://doi.org/10.1097/md.0000000000007916 (2017).

4. Woodroffe, R. W., Helland, L. C., Grossbach, A. J., Nourski, K. V. \& Hitchon, P. W. Risk factors associated with reoperation in posterior cervical fusions: A large-scale retrospective analysis. Clin Neurol Neurosurg, 195, 105828 https://doi.org/10.1016/j.clineuro.2020.105828 (2020).

5. Smoking-attributable mortality. years of potential life lost, and productivity losses-United States, 2000-2004. MMWR Morb Mortal Wkly Rep, 57, 12261228 (2008).

6. De la Ramos, G. R. et al. Impact of Smoking on 30-day Morbidity and Mortality in Adult Spinal Deformity Surgery. Spine (Phila Pa 1976), 42, 465-470 https://doi.org/10.1097/brs.0000000000001795 (2017).

7. Siemionow, K., Tyrakowski, M., Patel, K. \& Neckrysh, S. Comparison of perioperative complications following staged versus one-day anterior and posterior cervical decompression and fusion crossing the cervico-thoracic junction. Neurol Neurochir Pol, 48, 403-409 https://doi.org/10.1016/j.pjnns.2014.10.001 (2014).

8. Elsamadicy, A. A. et al. Reduced Impact of Smoking Status on 30-Day Complication and Readmission Rates After Elective Spinal Fusion ( $\geq 3$ Levels) for Adult Spine Deformity: A Single Institutional Study of 839 Patients. World Neurosurg, 107, 233-238 https://doi.org/10.1016/j.wneu.2017.07.174 (2017).

9. Hilibrand, A. S., Fye, M. A., Emery, S. E., Palumbo, M. A. \& Bohlman, H. H. Impact of smoking on the outcome of anterior cervical arthrodesis with interbody or strut-grafting. J Bone Joint Surg Am, 83, 668-673 https://doi.org/10.2106/00004623-200105000-00004 (2001).

10. Martin Jr, G. J., Haid, R. W. Jr, Macmillan, M., Rodts Jr, G. E. \& Berkman, R. Anterior cervical discectomy with freeze-dried fibula allograft: Overview of 317 cases and literature review. Spine, 24, 852-859 https://doi.org/10.1097/00007632-199905010-00004 (1999).

11. Lau, D., Chou, D., Ziewacz, J. E. \& Mummaneni, P. V. The effects of smoking on perioperative outcomes and pseudarthrosis following anterior cervical corpectomy: Clinical article. J Neurosurg Spine, 21, 547-558 https://doi.org/10.3171/2014.6.Spine13762 (2014).

12. Badiee, R. K. et al. Smoking Is an Independent Risk Factor for 90-Day Readmission and Reoperation Following Posterior Cervical Decompression and Fusion. Neurosurgery, 88, 1088-1094 https://doi.org/10.1093/neuros/nyaa593 (2021).

13. Wen-Shen, L. et al. No difference in functional outcome but higher revision rate among smokers undergoing cervical artificial disc replacement: Analysis of a spine registry. International Journal of Spine Surgery, 14, 916-923 https://doi.org/10.14444/7140 (2020).

14. Pahys, J. M. et al. Methods to Decrease Postoperative Infections Following Posterior Cervical Spine Surgery. Journal of Bone and Joint Surgery-American Volume 95A, 549-554, doi:10.2106/jbjs.K.00756 (2013).

15. Zhang, X. et al. Factors associated with postoperative axial symptom after expansive open-door laminoplasty: retrospective study using multivariable analysis. Eur Spine J, 29, 2838-2844 https://doi.org/10.1007/s00586-020-06494-5 (2020).

16. Huang, C. Y. et al. The effect of the difference in C2-7angle on the occurrence of dysphagia after anterior cervical discectomy and fusion with the zero-P implant system. BMC Musculoskeletal Disorders, 21, https://doi.org/10.1186/s12891-020-03691-7 (2020).

17. Shi, S. et al. Risk Factors for Dysphagia After Single-Level Anterior Cervical Decompression with Arthroplasty or Fusion: A Prospective Study Comparing 2 Zero-Profile Implants. World Neurosurg, 95, 148-155 https://doi.org/10.1016/j.wneu.2016.07.100 (2016).

18. Tu, T. H. et al. Effects of smoking on cervical disc arthroplasty. J Neurosurg Spine, 30, 168-174 https://doi.org/10.3171/2018.7.Spine18634 (2019).

19. Cerier, E. et al. Smoking is Associated With 1-year Suboptimal Patient-reported Outcomes After 2-level Anterior Cervical Fusion. Clin Spine Surg, 32, 175178 https://doi.org/10.1097/bsd.0000000000000765 (2019).

20. Bose, B. Anterior cervical instrumentation enhances fusion rates in multilevel reconstruction in smokers. J Spinal Disord, 14, 3-9 https://doi.org/10.1097/00002517-200102000-00002 (2001).

21. Vasquez, R. A. et al. The Profile of a Smoker and Its Impact on Outcomes after Cervical Spine Surgery. Neurosurgery, 63, 96-101 https://doi.org/10.1227/NEU.0000000000001284 (2016).

22. Medvedev, G. et al. Readmissions, and Reoperations in Posterior Cervical Fusion. Spine, 41, 1477-1483 https://doi.org/10.1097/brs.0000000000001564 (2016).

23. Stroup, D. F. et al. Meta-analysis of observational studies in epidemiology: a proposal for reporting. Meta-analysis Of Observational Studies in Epidemiology (MOOSE) group., 283, 2008-2012 https://doi.org/10.1001/jama.283.15.2008 (2000).

24. Stang, A. Critical evaluation of the Newcastle-Ottawa scale for the assessment of the quality of nonrandomized studies in meta-analyses. Eur $J$ Epidemiol, 25, 603-605 https://doi.org/10.1007/s10654-010-9491-z (2010).

25. Centre, T. (The Cochrane Collaboration Copenhagen, 2014). 
26. Higgins, J. P. \& Thompson, S. G. Quantifying heterogeneity in a meta-analysis. Stat. Med, 21, 1539-1558 https://doi.org/10.1002/sim.1186 (2002).

27. Higgins, J. P., Thompson, S. G., Deeks, J. J. \& Altman, D. G. Measuring inconsistency in meta-analyses., 327, 557-560

https://doi.org/10.1136/bmj.327.7414.557 (2003).

28. Begg, C. B. \& Mazumdar, M. Operating characteristics of a rank correlation test for publication bias., 50, 1088-1101 (1994).

29. Egger, M., Davey Smith, G., Schneider, M. \& Minder, C. Bias in meta-analysis detected by a simple, graphical test. BMJ, 315, 629-634 https://doi.org/10.1136/bmj.315.7109.629 (1997).

30. Analysis of harvest morbidity and radiographic outcome using autograft for anterior cervical fusion.

31. Agrillo, U., Mastronardi, L. \& Puzzilli, F. Anterior cervical fusion with carbon fiber cage containing coralline hydroxyapatite: preliminary observations in 45 consecutive cases of soft-disc herniation. J Neurosurg, 96, 273-276 https://doi.org/10.3171/spi.2002.96.3.0273 (2002).

32. An, H. S., Simpson, J. M., Glover, J. M. \& Stephany, J. Comparison between allograft plus demineralized bone matrix versus autograft in anterior cervical fusion. A prospective multicenter study. Spine (Phila Pa 1976) 20, 2211-2216 (1995).

33. Bergin, S. M. et al. Pseudarthrosis rate following anterior cervical discectomy with fusion using an allograft cellular bone matrix: a multi-institutional analysis. Neurosurg Focus, 50, E6 https://doi.org/10.3171/2021.3.FOCUS2166 (2021).

34. Chen, B. et al. Risk factors for dysphagia after single-level anterior cervical fusion. Chinese Journal of Tissue Engineering Research, 19, $2028-2033$ https://doi.org/10.3969/j.issn.2095-4344.2015.13.012 (2015).

35. Dube, S. K., Chaturvedi, A., Kumar, S. \& Pandia, M. P. Retrospective study of postoperative pulmonary complications in patients with cervical spine pathology. Journal of Neuroanaesthesiology and Critical Care, 5, 98-104 https://doi.org/10.1055/s-0038-1660876 (2018).

36. Eubanks, J. D., Thorpe, S. W., Cheruvu, V. K., Braly, B. A. \& Kang, J. D. Does smoking influence fusion rates in posterior cervical arthrodesis with lateral mass instrumentation? Clin Orthop Relat Res, 469, 696-701 https://doi.org/10.1007/s11999-010-1575-2 (2011).

37. Goldberg, E. J., Singh, K., Van, U., Garretson, R. \& An, H. S. Comparing outcomes of anterior cervical discectomy and fusion in workman's versus nonworkman's compensation population. Spine J, 2, 408-414 https://doi.org/10.1016/S1529-9430(02)00441-2 (2002).

38. Groff, M. W., Sriharan, S., Lee, S. M. \& Maiman, D. J. Partial corpectomy for cervical spondylosis. Spine (Phila Pa 1976) 28, 14-20, doi:10.1097/00007632200301010-00005 (2003).

39. Kang, S. S., Lee, J. S., Shin, J. K., Lee, J. M. \& Youn, B. H. The association between psychiatric factors and the development of chronic dysphagia after anterior cervical spine surgery. Eur Spine J, 23, 1694-1698 https://doi.org/10.1007/s00586-014-3281-3 (2014).

40. Kimura, A., Shiraishi, Y., Inoue, H., Endo, T. \& Takeshita, K. Predictors of Persistent Axial Neck Pain After Cervical Laminoplasty. Spine (Phila Pa 1976) 43, 10-15, doi:10.1097/brs.0000000000002267 (2018).

41. Klement, M. R. et al. C5 palsy after cervical laminectomy and fusion: does width of laminectomy matter? Spine J, 16, 462-467 https://doi.org/10.1016/j.spinee.2015.07.437 (2016).

42. Lee, J. C., Lee, S. H., Peters, C. \& Riew, K. D. Risk-factor analysis of adjacent-segment pathology requiring surgery following anterior, posterior, fusion, and nonfusion cervical spine operations: Survivorship analysis of 1358 patients. Journal of Bone and Joint Surgery - American Volume, 96, 1761-1767 https://doi.org/10.2106/JBJS.M.01482 (2014).

43. Lee, J. C., Lee, S. H., Peters, C. \& Riew, K. D. Adjacent segment pathology requiring reoperation after anterior cervical arthrodesis: the influence of smoking, sex, and number of operated levels. Spine (Phila Pa 1976), 40, E571-577 https://doi.org/10.1097/brs.0000000000000846 (2015).

44. Liang, J., Hu, J., Chen, C., Yin, H. \& Dong, F. Risk factors for predicting increased surgical drain output in patients after anterior cervical corpectomy and fusion. J Orthop Surg Res, 12, 196 https://doi.org/10.1186/s13018-017-0698-5 (2017).

45. Liu, S. et al. Prevalence and risk factors of axial neck pain in patients undergoing multilevel anterior cervical decompression with fusion surgery. $J$ Orthop Surg Res, 14, 94 https://doi.org/10.1186/s13018-019-1132-y (2019).

46. Luszczyk, M. et al. Does smoking have an impact on fusion rate in single-level anterior cervical discectomy and fusion with allograft and rigid plate fixation? Clinical article. J Neurosurg Spine, 19, 527-531 https://doi.org/10.3171/2013.7.Spine13208 (2013).

47. Mangan, J. J. et al. Does Smoking Status Influence Health-Related Quality of Life Outcome Measures in Patients Undergoing ACDF? Global Spine Journal, 11, 50-56 https://doi.org/10.1177/2192568219890292 (2021).

48. Nakashima, H. et al. Characterizing the need for tracheostomy placement and decannulation after cervical spinal cord injury. Eur Spine J, 22, 1526-1532 https://doi.org/10.1007/s00586-013-2762-0 (2013).

49. Patel, D. V., Yoo, J. S., Lamoutte, E. H., Karmarkar, S. S. \& Singh, K. The Effect of Tobacco Use on Postoperative Pain Following Anterior Cervical Discectomy and Fusion. Clin Spine Surg, 32, E440-e443 https://doi.org/10.1097/bsd.0000000000000830 (2019).

50. Plano, X. et al. 30-Day unplanned surgery in cervical spondylotic myelopathy surgically treated: a single-center experience. Eur Spine J, 28, $1209-1216$ https://doi.org/10.1007/s00586-019-05892-8 (2019).

51. Ren, B., Gao, W., An, J., Wu, M. \& Shen, Y. Risk factors of cage nonunion after anterior cervical discectomy and fusion. Med. (Baltim), 99 , e19550 https://doi.org/10.1097/md.0000000000019550 (2020).

52. Riederman, B. D. et al. Recombinant human bone morphogenetic protein-2 versus iliac crest bone graft in anterior cervical discectomy and fusion: Dysphagia and dysphonia rates in the early postoperative period with review of the literature. J Clin Neurosci, 44, 180-183 https://doi.org/10.1016/j.jocn.2017.06.034 (2017).

53. Sagi, H. C., Beutler, W., Carroll, E. \& Connolly, P. J. Airway complications associated with surgery on the anterior cervical spine. Spine (Phila Pa 1976), 27, 949-953 https://doi.org/10.1097/00007632-200205010-00013 (2002).

Page $14 / 23$ 
54. Suchomel, P., Barsa, P., Buchvald, P., Svobodnik, A. \& Vanickova, E. Autologous versus allogenic bone grafts in instrumented anterior cervical discectomy and fusion: a prospective study with respect to bone union pattern. Eur Spine J, 13, 510-515 https://doi.org/10.1007/s00586-003-0667-z (2004).

55. Wang, J. C., McDonough, P. W., Endow, K., Kanim, L. E. \& Delamarter, R. B. The effect of cervical plating on single-level anterior cervical discectomy and fusion. J Spinal Disord, 12, 467-471 (1999).

56. Wang, J. C., McDonough, P. W., Endow, K. K. \& Delamarter, R. B. Increased fusion rates with cervical plating for two-level anterior cervical discectomy and fusion. Spine (Phila Pa 1976), 25, 41-45 https://doi.org/10.1097/00007632-200001010-00009 (2000).

57. (!!! INVALID CITATION !!! 3,9-11,16,18-20,30-34,37-39,43-47,49,51-56).

58. Jain, A., Hassanzadeh, H., Strike, S. A., Skolasky, R. L. \& Riley, L. H. 3 rhBMP use in cervical spine surgery: associated factors and in-hospital complications. J Bone Joint Surg Am, 96, 617-623 https://doi.org/10.2106/jbjs.M.00666 (2014).

59. Fehlings, M. G. et al. Perioperative and delayed complications associated with the surgical treatment of cervical spondylotic myelopathy based on 302 patients from the AOSpine North America Cervical Spondylotic Myelopathy Study Presented at the 2011 Spine Section Meeting Clinical article. Journal of Neurosurgery-Spine, 16, 425-432 https://doi.org/10.3171/2012.1.Spine11467 (2012).

60. Noronha-Dutra, A. A., Epperlein, M. M. \& Woolf, N. Effect of cigarette smoking on cultured human endothelial cells. Cardiovasc. Res, 27, 774-778 https://doi.org/10.1093/cvr/27.5.774 (1993).

61. Brinker, M. R., Lippton, H. L., Cook, S. D. \& Hyman, A. L. Pharmacological regulation of the circulation of bone. J Bone Joint Surg Am, 72, $964-975$ (1990).

62. Nadler, J. L., Velasco, J. S. \& Horton, R. Cigarette smoking inhibits prostacyclin formation., 1, 1248-1250 https://doi.org/10.1016/s0140-6736(83)92698-3 (1983).

63. Pittilo, R. M., Mackie, I. J., Rowles, P. M., Machin, S. J. \& Woolf, N. Effects of cigarette smoking on the ultrastructure of rat thoracic aorta and its ability to produce prostacyclin. Thromb. Haemost, 48, 173-176 (1982).

64. Sonnenfeld, T. \& Wennmalm, A. Inhibition by nicotine of the formation of prostacyclin-like activity in rabbit and human vascular tissue. Br. J. Pharmacol, 71, 609-613 https://doi.org/10.1111/j.1476-5381.1980.tb10980.x (1980).

65. Hunt, T. K. \& Pai, M. P. The effect of varying ambient oxygen tensions on wound metabolism and collagen synthesis. Surg Gynecol Obstet, 135, 561-567 (1972).

66. Hambly, M. F. \& Mooney, V. Effect of smoking and pulsed electromagnetic fields on intradiscal pH in rabbits. Spine, 17, S83-85 https://doi.org/10.1097/00007632-199206001-00004 (1992).

67. Zheng, Y. H. et al. A novel Keap1 inhibitor iKeap1 activates Nrf2 signaling and ameliorates hydrogen peroxide-induced oxidative injury and apoptosis in osteoblasts. Cell Death Dis, 12, 679 https://doi.org/10.1038/s41419-021-03962-8 (2021).

68. Elia, C. J. et al. Impact of chronic DMARD therapy in patients with rheumatoid arthritis undergoing surgery of the craniovertebral junction: A multi-center retrospective study. Spine, 45, 930-936 https://doi.org/10.1097/BRS.0000000000003402 (2020).

69. Pryor, W. A., Church, D. F., Evans, M. D., Rice, W. Y. Jr. \& Hayes, J. R. A comparison of the free radical chemistry of tobacco-burning cigarettes and cigarettes that only heat tobacco. Free Radical Biol. Med, 8, 275-279 https://doi.org/10.1016/0891-5849(90)90075-t (1990).

70. Pryor, W. A. Free radicals in biological systems. Sci. Am. 223, 70-76 passim, doi:10.1038/scientificamerican0870-70 (1970).

71. McCusker, K. \& Hoidal, J. Selective increase of antioxidant enzyme activity in the alveolar macrophages from cigarette smokers and smoke-exposed hamsters. Am Rev Respir Dis, 141, 678-682 https://doi.org/10.1164/ajrccm/141.3.678 (1990).

72. Lehr, H. A. et al. Cigarette smoke elicits leukocyte adhesion to endothelium in hamsters: inhibition by CuZn-SOD. Free Radical Biol. Med, 14, 573-581 https://doi.org/10.1016/0891-5849(93)90138-k (1993).

73. Kalra, J., Chaudhary, A. K. \& Prasad, K. Increased production of oxygen free radicals in cigarette smokers. Int. J. Exp. Pathol, 72, 1-7 (1991).

74. Pearson, R. G., Clement, R. G., Edwards, K. L. \& Scammell, B. E. Do smokers have greater risk of delayed and non-union after fracture, osteotomy and arthrodesis? A systematic review with meta-analysis. BMJ Open, 6, e010303 https://doi.org/10.1136/bmjopen-2015-010303 (2016).

75. Silcox, D. H. et al. 3rd The effect of nicotine on spinal fusion. Spine 20, 1549-1553, doi:10.1097/00007632-199507150-00001 (1995).

76. Zhang, Y., He, J., He, B., Huang, R. \& Li, M. Effect of tobacco on periodontal disease and oral cancer. Tob. Induc. Dis, 17, 40 https://doi.org/10.18332/tid/106187 (2019).

77. Qian, Q. Z., Cao, X. K., Shen, F. H. \& Wang, Q. Correlations of smoking with cumulative total dust exposure and cumulative abnormal rate of pulmonary function in coal-mine workers. Exp Ther Med, 12, 2942-2948 https://doi.org/10.3892/etm.2016.3700 (2016).

78. Pearson, R. G., Clement, R. G. E., Edwards, K. L. \& Scammell, B. E. Do smokers have greater risk of delayed and non-union after fracture, osteotomy and arthrodesis? A systematic review with meta-analysis. \#N/A, 6, https://doi.org/10.1136/bmjopen-2015-010303 (2016).

79. Martin, C. T., Gao, Y., Duchman, K. R. \& Pugely, A. J. The Impact of Current Smoking and Smoking Cessation on Short-Term Morbidity Risk After Lumbar Spine Surgery. Spine (Phila Pa 1976) 41, 577-584, doi:10.1097/brs.0000000000001281 (2016).

80. Purvis, T. E. et al. Impact of smoking on postoperative complications after anterior cervical discectomy and fusion. J Clin Neurosci, 38, $106-110$ https://doi.org/10.1016/j.jocn.2016.12.044 (2017).

81. Grønkjær, M. et al. Preoperative smoking status and postoperative complications: a systematic review and meta-analysis. Ann. Surg, 259, 52-71 https://doi.org/10.1097/SLA.0b013e3182911913 (2014).

82. Sørensen, L. T. Wound healing and infection in surgery. The clinical impact of smoking and smoking cessation: a systematic review and meta-analysis. Arch Surg, 147, 373-383 https://doi.org/10.1001/archsurg.2012.5 (2012). 
83. Andersen, T. et al. Smoking as a predictor of negative outcome in lumbar spinal fusion. Spine, 26, 2623-2628 https://doi.org/10.1097/00007632200112010-00018 (2001).

84. Sørensen, L. T. Wound healing and infection in surgery: the pathophysiological impact of smoking, smoking cessation, and nicotine replacement therapy: a systematic review. Ann Surg, 255, 1069-1079 https://doi.org/10.1097/SLA.0b013e31824f632d (2012).

\section{Figures}
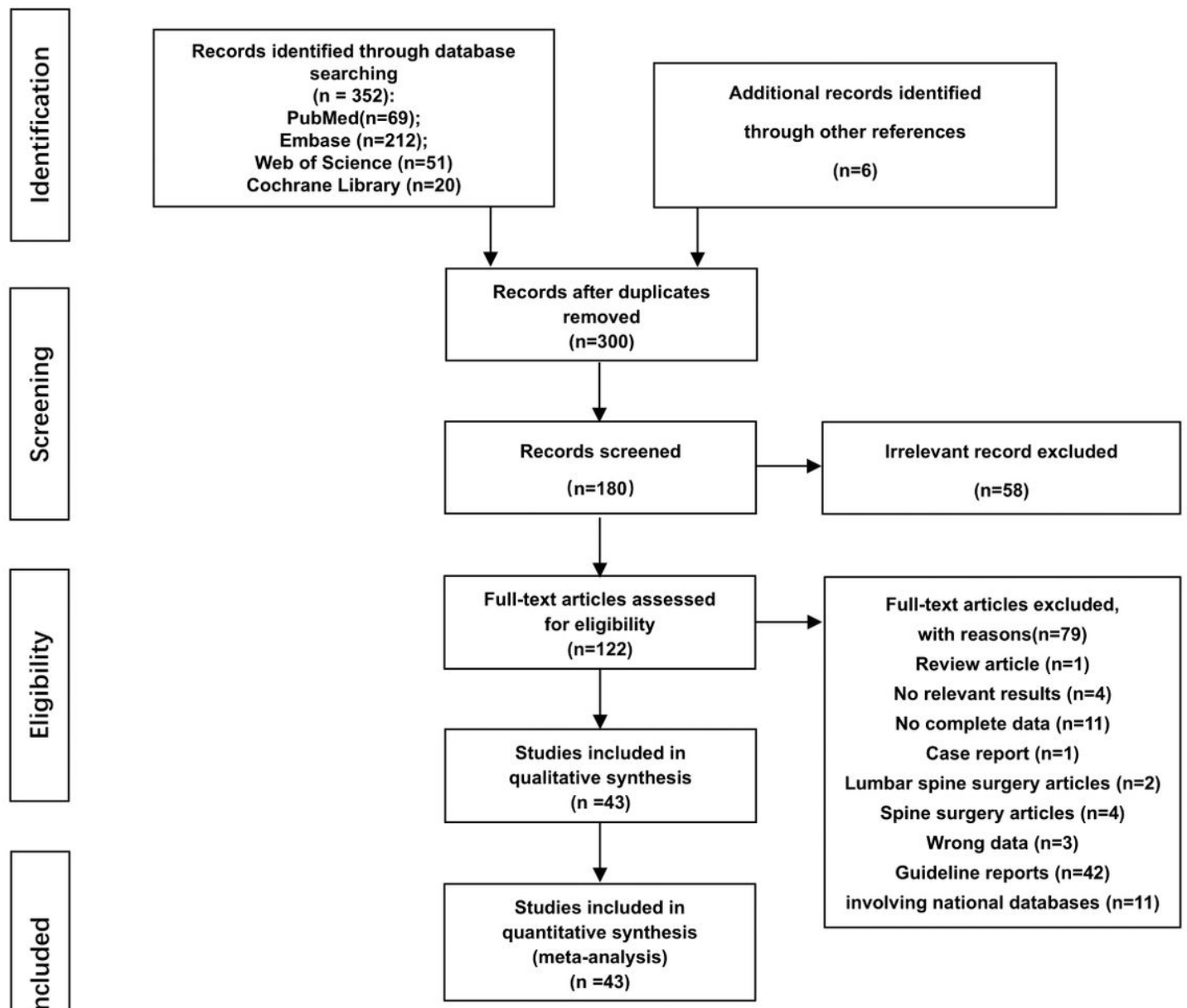

\section{Figure 1}

Flow diagram of study selection 


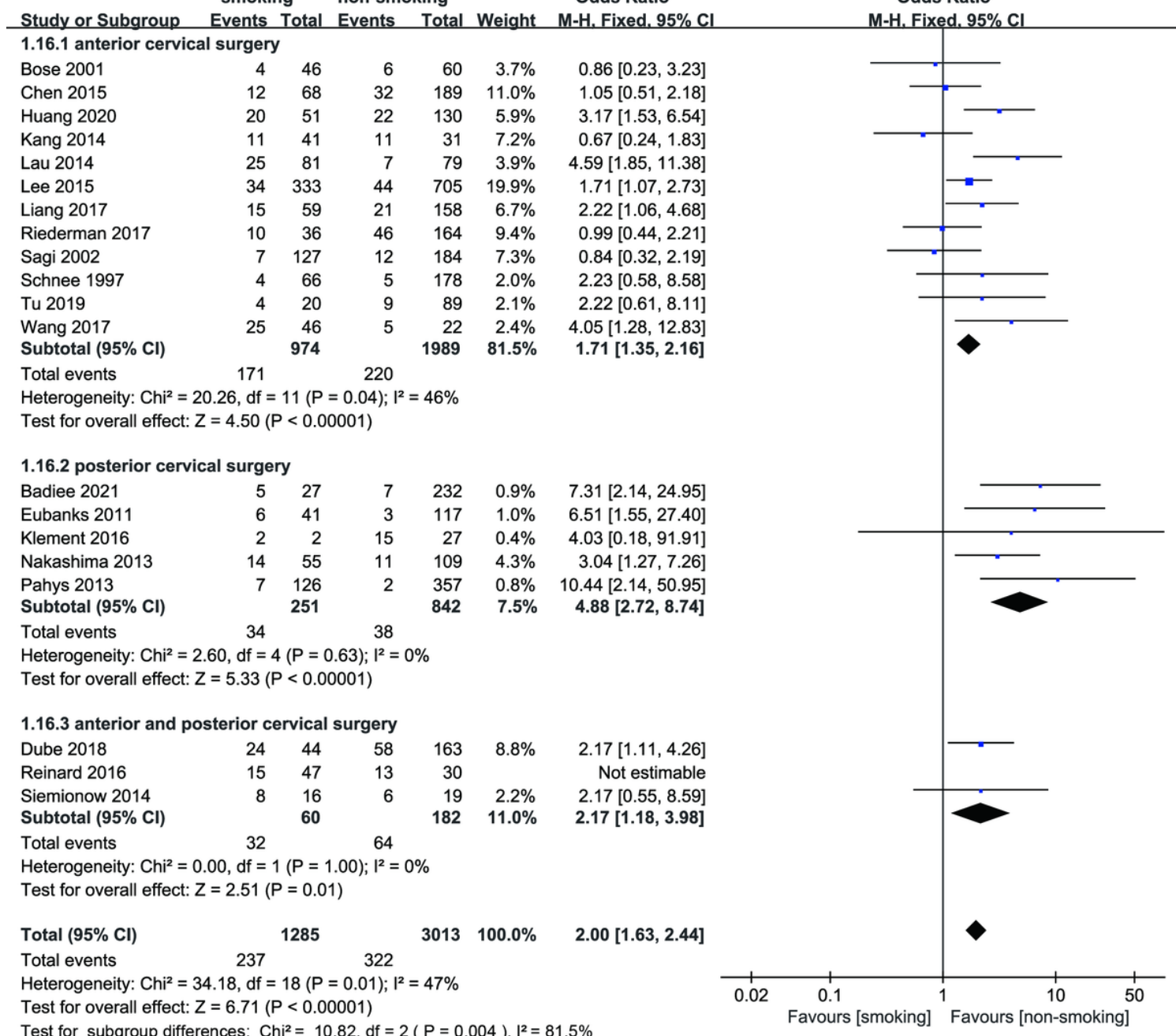

Test for subgroup differences: $\mathrm{Chi}^{2}=10.82 . \mathrm{df}=2(\mathrm{P}=0.004) . \mathrm{I}^{2}=81.5 \%$

Figure 2

Forest plot showing the effect of smoking on overall complications. $\mathrm{Cl}$, confidence interval; df, degree of freedom; M-H, Mantel-Haenszel.

Smoking Non-smoking Odds Ratio

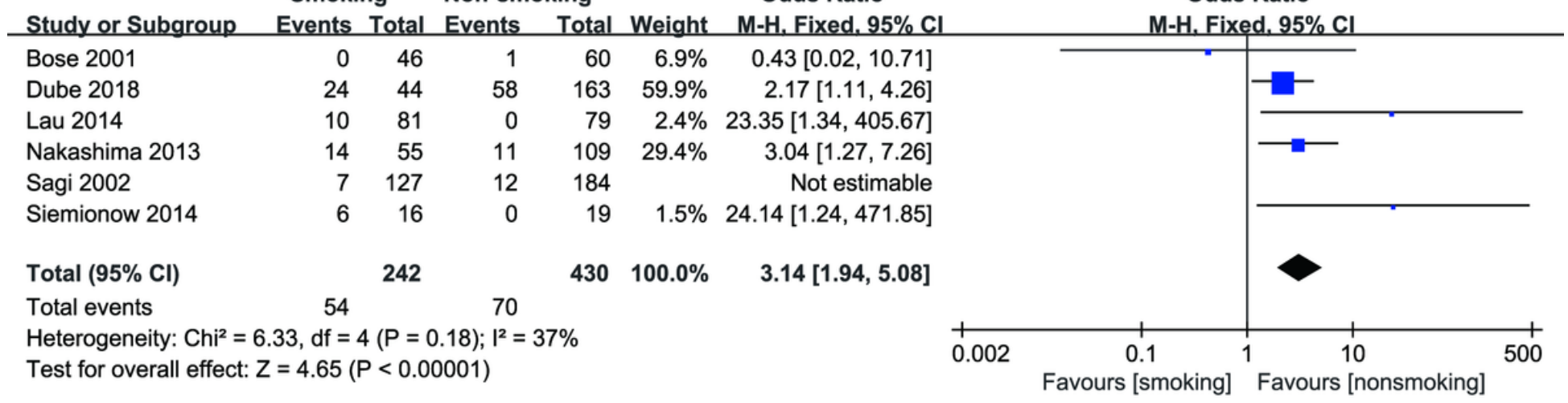

Figure 3

Forest plot showing the effect of smoking on respiratory complications. $\mathrm{Cl}$, confidence interval; df, degree of freedom; $\mathrm{M}-\mathrm{H}$, Mantel-Haenszel. 
Smoking Non-smoking

Study or Subgroup

Badiee 2021

Bose 2001

Lau 2014

Lee 2014

Mangan 2021

Plano 2019

Wen-Shen 2020

Woodroffe 2020

Total $(95 \% \mathrm{Cl})$

Total events

Heterogeneity: $\mathrm{Chi}^{2}=9.86, \mathrm{df}=6(\mathrm{P}=0.13) ; \mathrm{I}^{2}=39 \%$

Test for overall effect: $Z=3.46(P=0.0005)$
Odds Ratio

Odds Ratio

Events Total Events Total Weight M-H. Fixed, 95\% C

$7.31[2.14,24.95]$

$0.64[0.11,3.64]$

$0.77[0.20,2.97]$

$3.26[0.75,14.30]$

Not estimable

$2.33[0.55,9.94]$

$5.60[1.36,23.06]$

$2.26[1.10,4.62]$

$931 \quad 100.0 \% \quad 2.22[1.41,3.49]$
$\mathrm{M}-\mathrm{H}$. Fixed, $95 \% \mathrm{Cl}$

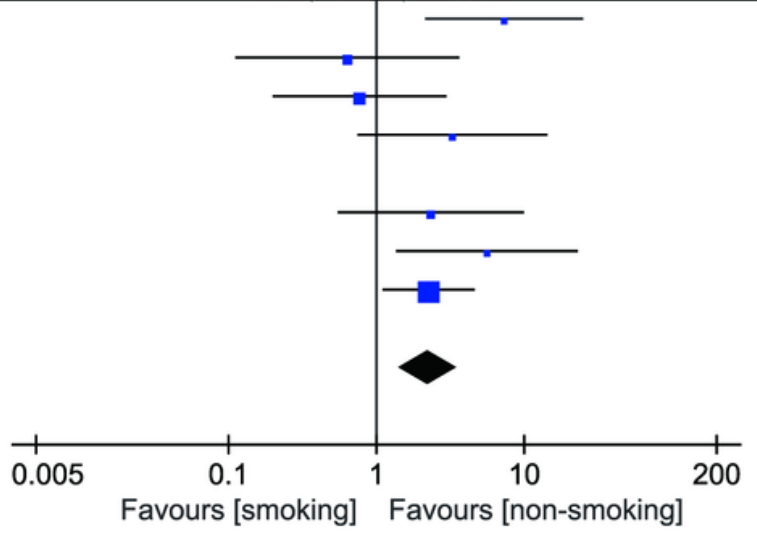

Figure 4

Forest plot showing the effect of smoking on reoperation. $\mathrm{Cl}$, confidence interval; df, degree of freedom; M-H, Mantel-Haenszel.

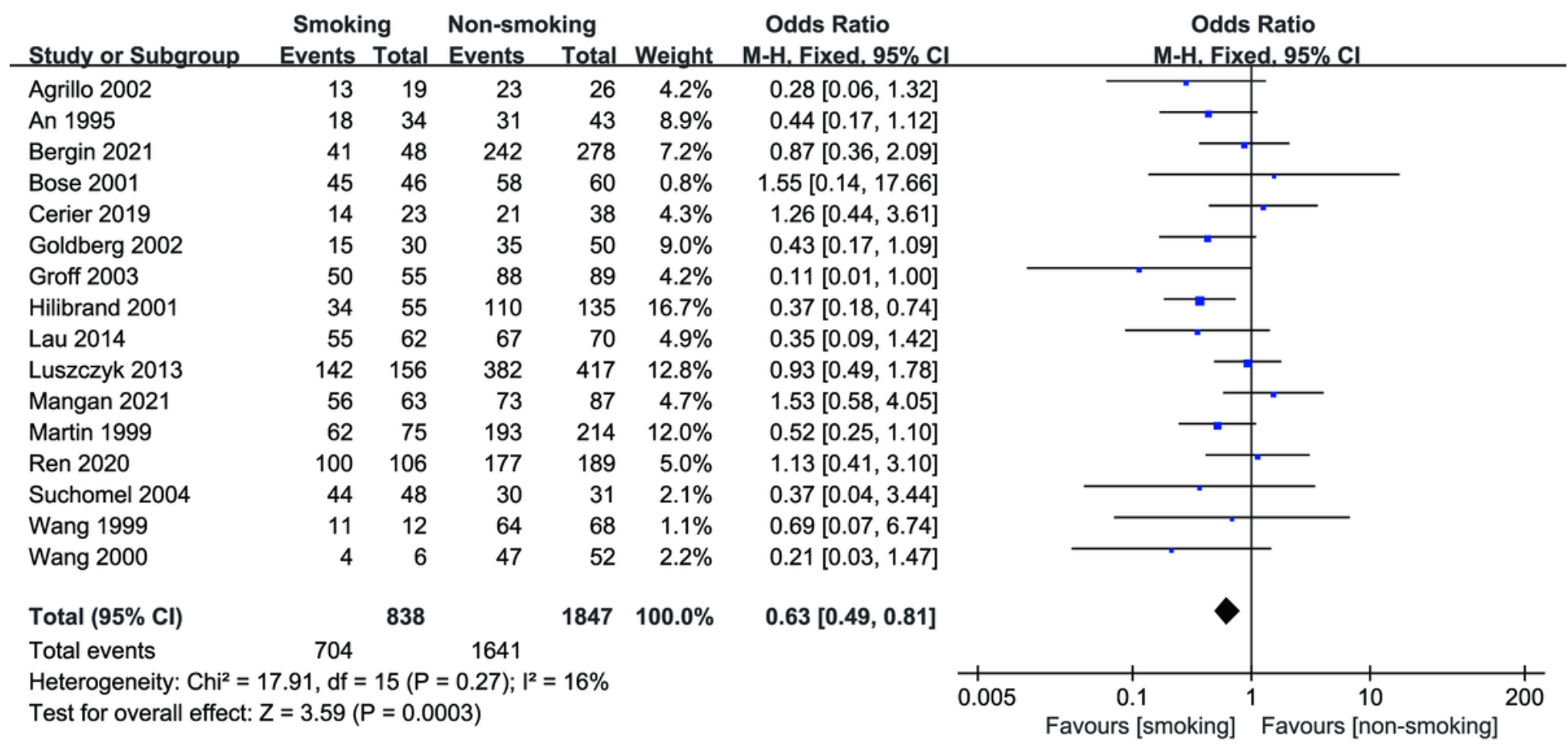

Figure 5

Forest plot showing the effect of smoking fusion rate. $\mathrm{Cl}$, confidence interval; df, degree of freedom; M-H, Mantel-Haenszel.

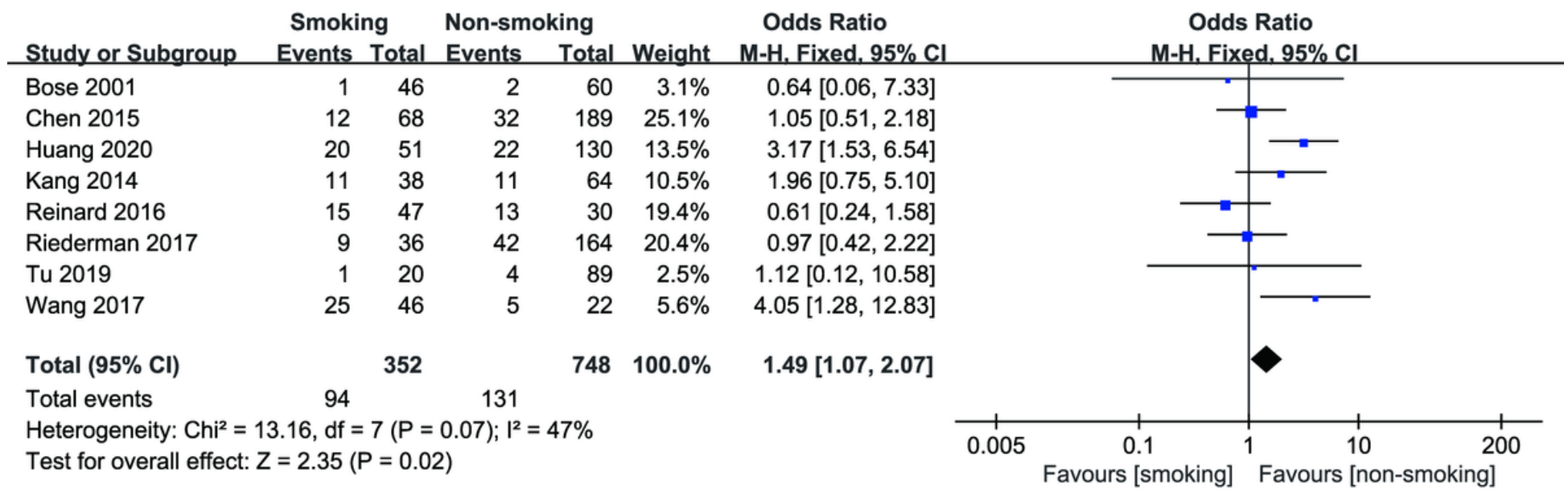


Figure 6

Forest plot showing the effect of smoking on dysphagia. $\mathrm{Cl}$, confidence interval; df, degree of freedom; M-H, Mantel-Haenszel.

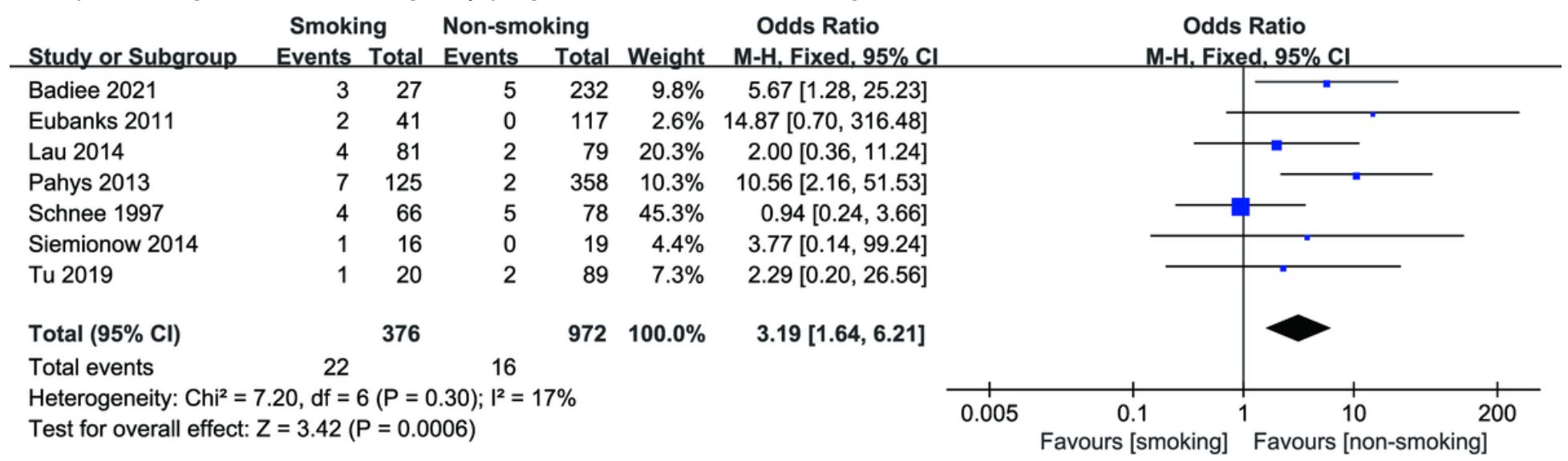

Figure 7

Forest plot showing the effect of smoking on wound infection. $\mathrm{Cl}$, confidence interval; df, degree of freedom; M-H, Mantel-Haenszel.

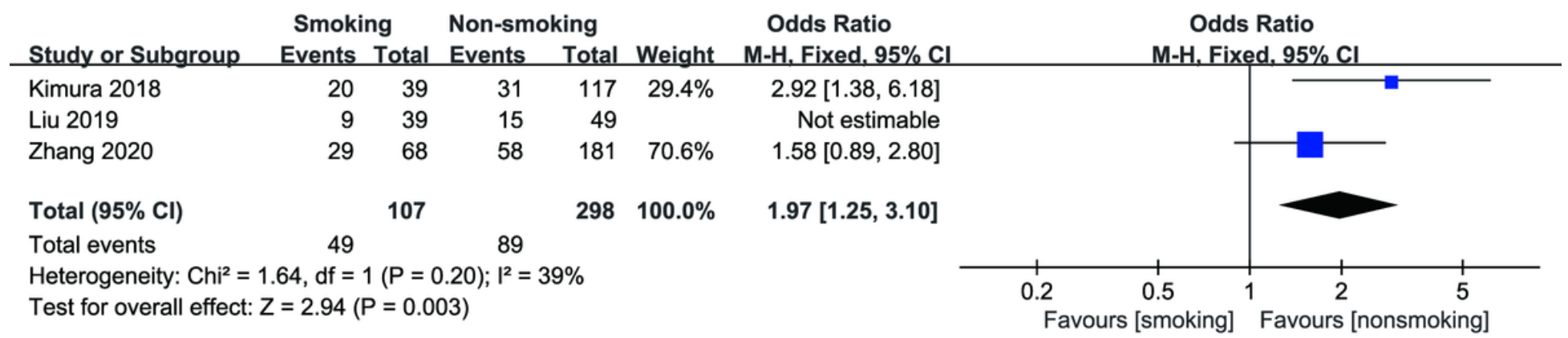

Figure 8

Forest plot showing the effect of smoking on axial neck pain. $\mathrm{Cl}$, confidence interval; df, degree of freedom; M-H, Mantel-Haenszel.

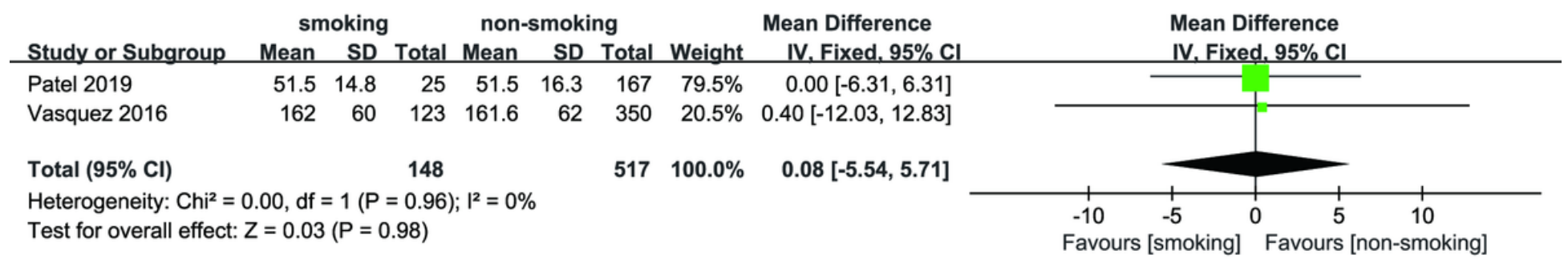

Figure 9

Forest plot showing the effect of smoking on operation time. Cl, confidence interval; df, degree of freedom; SD, standard deviation.

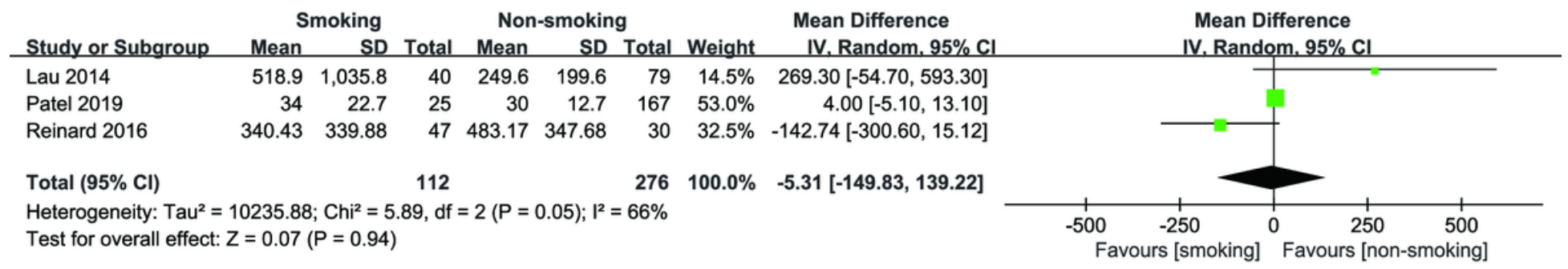

Figure 10

Forest plot showing the effect of smoking on estimated blood loss. Cl, confidence interval; df, degree of freedom; SD, standard deviation. 


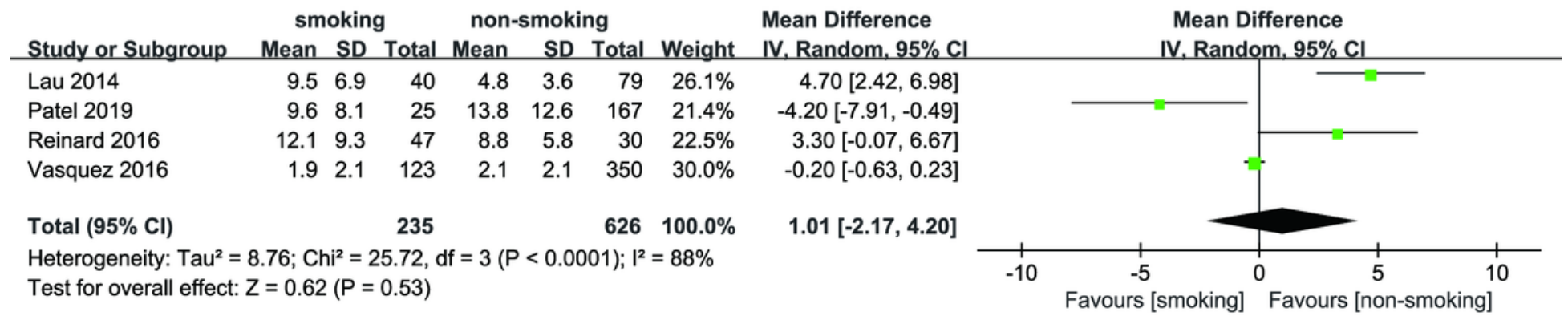

Figure 11

Forest plot showing the effect of smoking on length of hospital stay. $\mathrm{Cl}$, confidence interval; df, degree of freedom; SD, standard deviation.

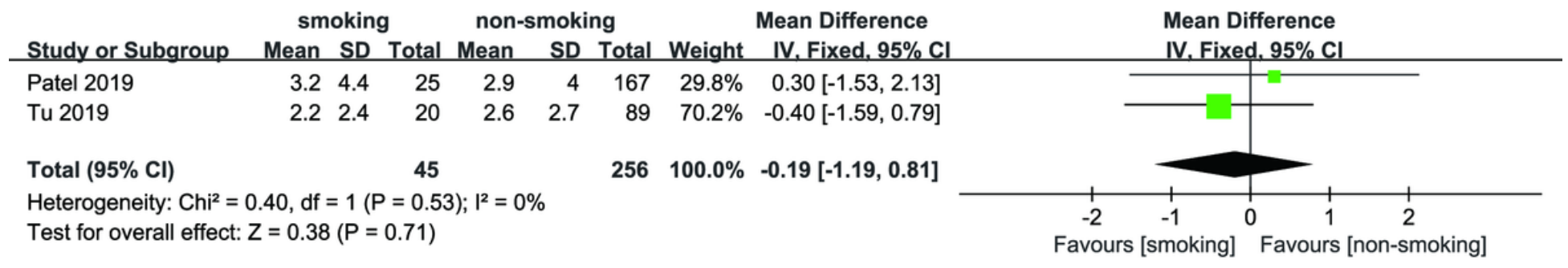

Figure 12

Forest plot showing the effect of smoking on VAS-neck pain. Cl, confidence interval; df, degree of freedom; SD, standard deviation.

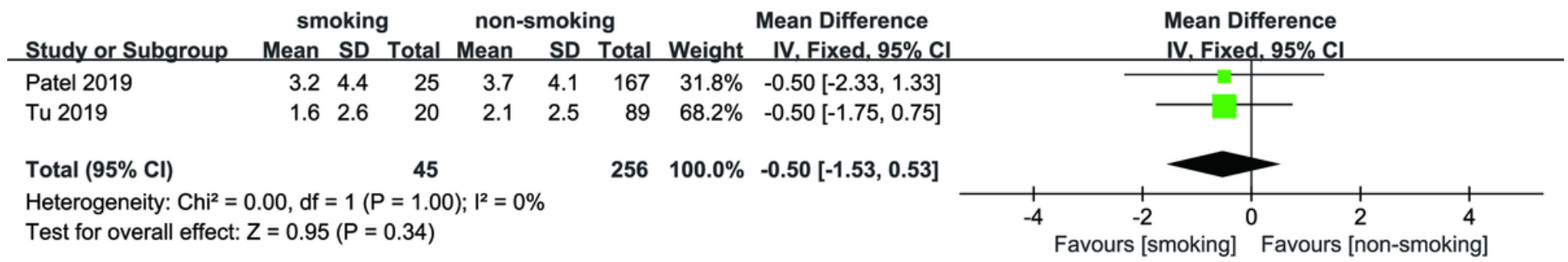

Figure 13

Forest plot showing the effect of smoking on VAS-arm pain. Cl, confidence interval; df, degree of freedom; SD, standard deviation.

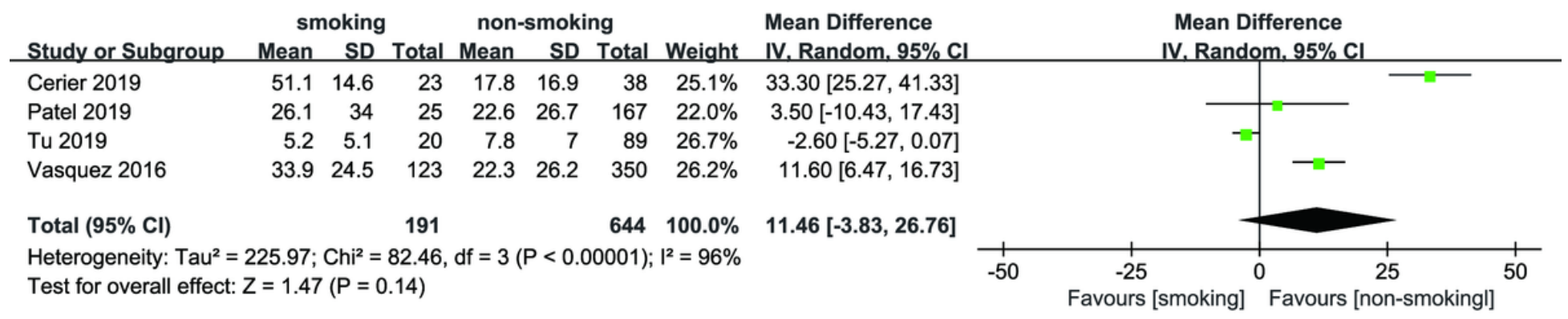

Figure 14

Forest plot showing the effect of smoking on NDI. Cl, confidence interval; df, degree of freedom; SD, standard deviation.

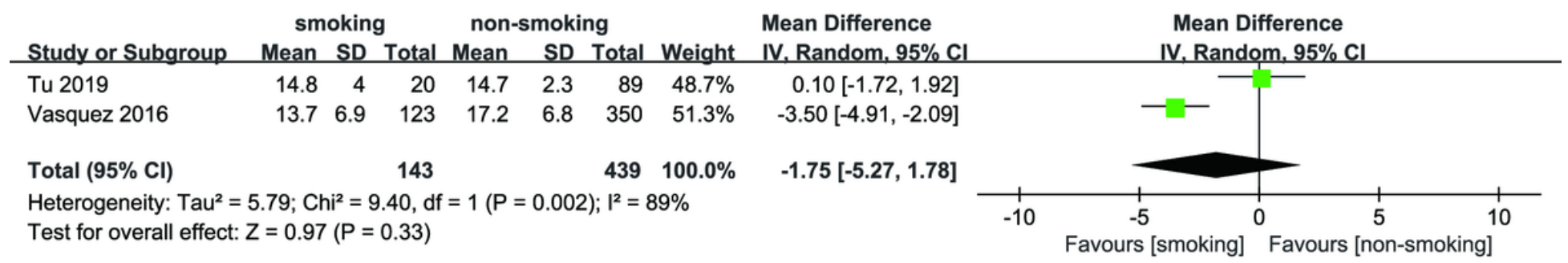


Forest plot showing the effect of smoking on JOA. Cl, confidence interval; df, degree of freedom; SD, standard deviation.

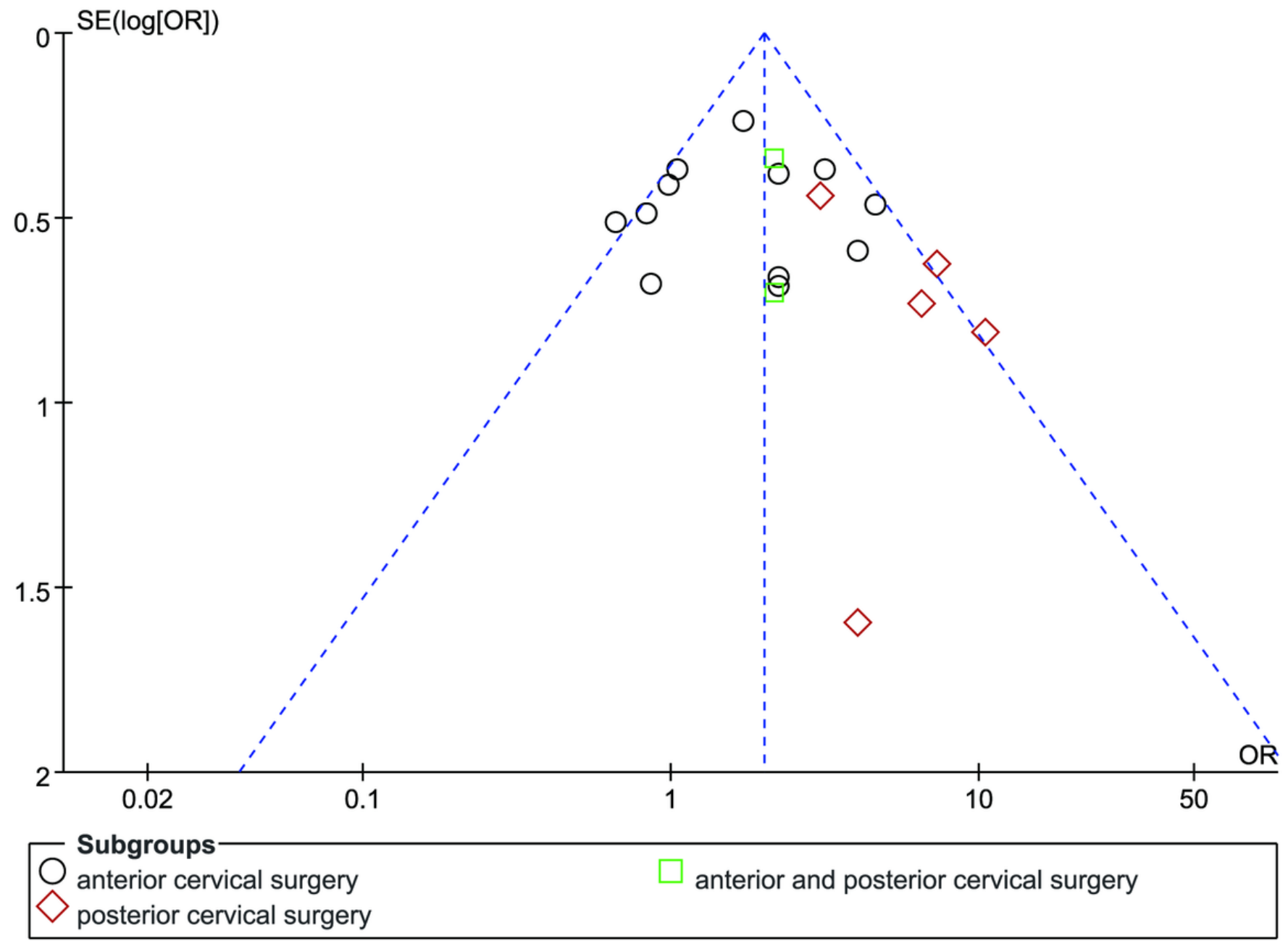

Figure 16

Funnel plot to evaluate the publication bias of overall complications. OR, odds ratio; SE, standard error. 


\section{Begg's funnel plot with pseudo $95 \%$ confidence limits}

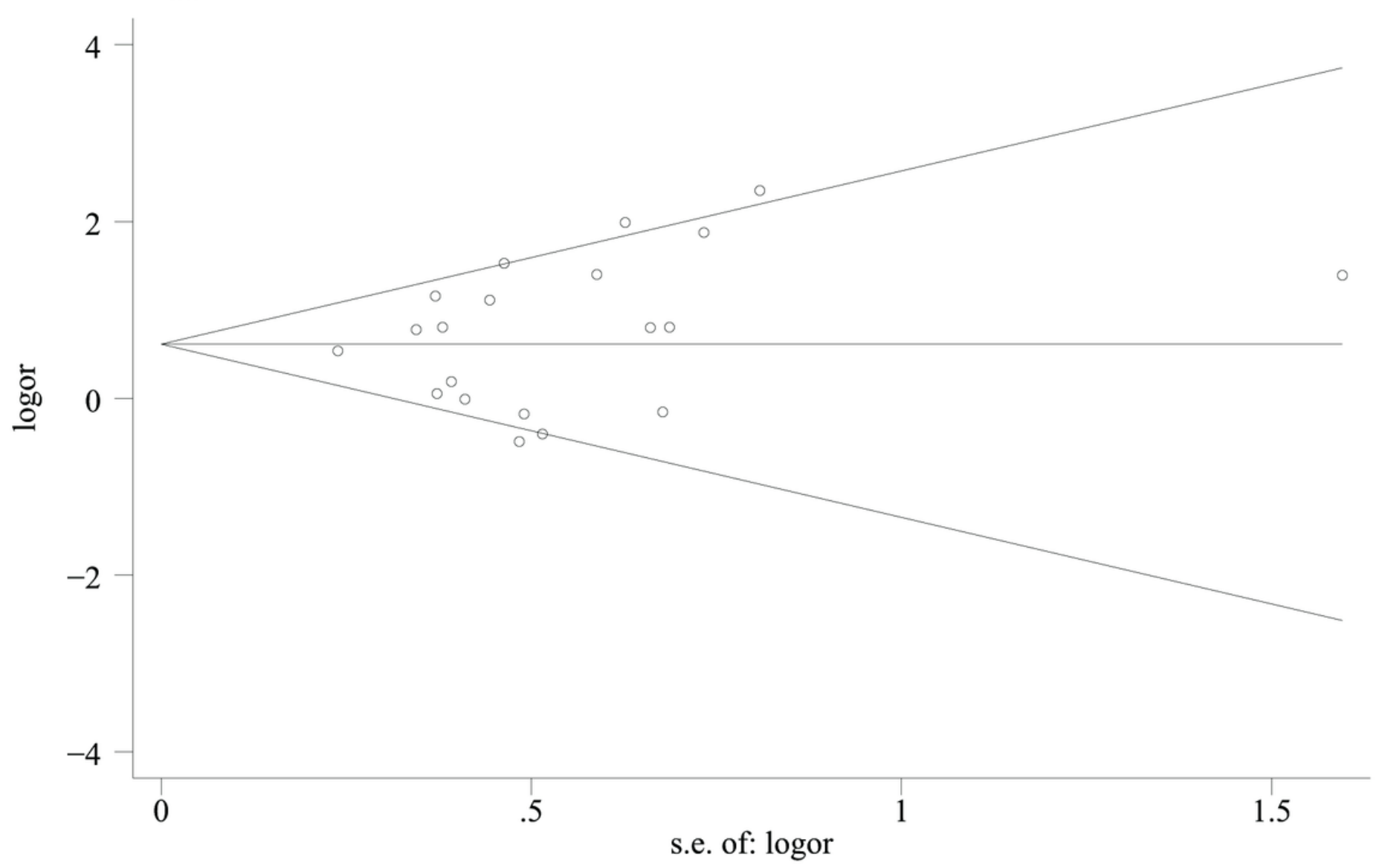

Figure 17

Begg's funnel plot to evaluate the publication bias of overall complications. 


\section{Egger's publication bias plot}

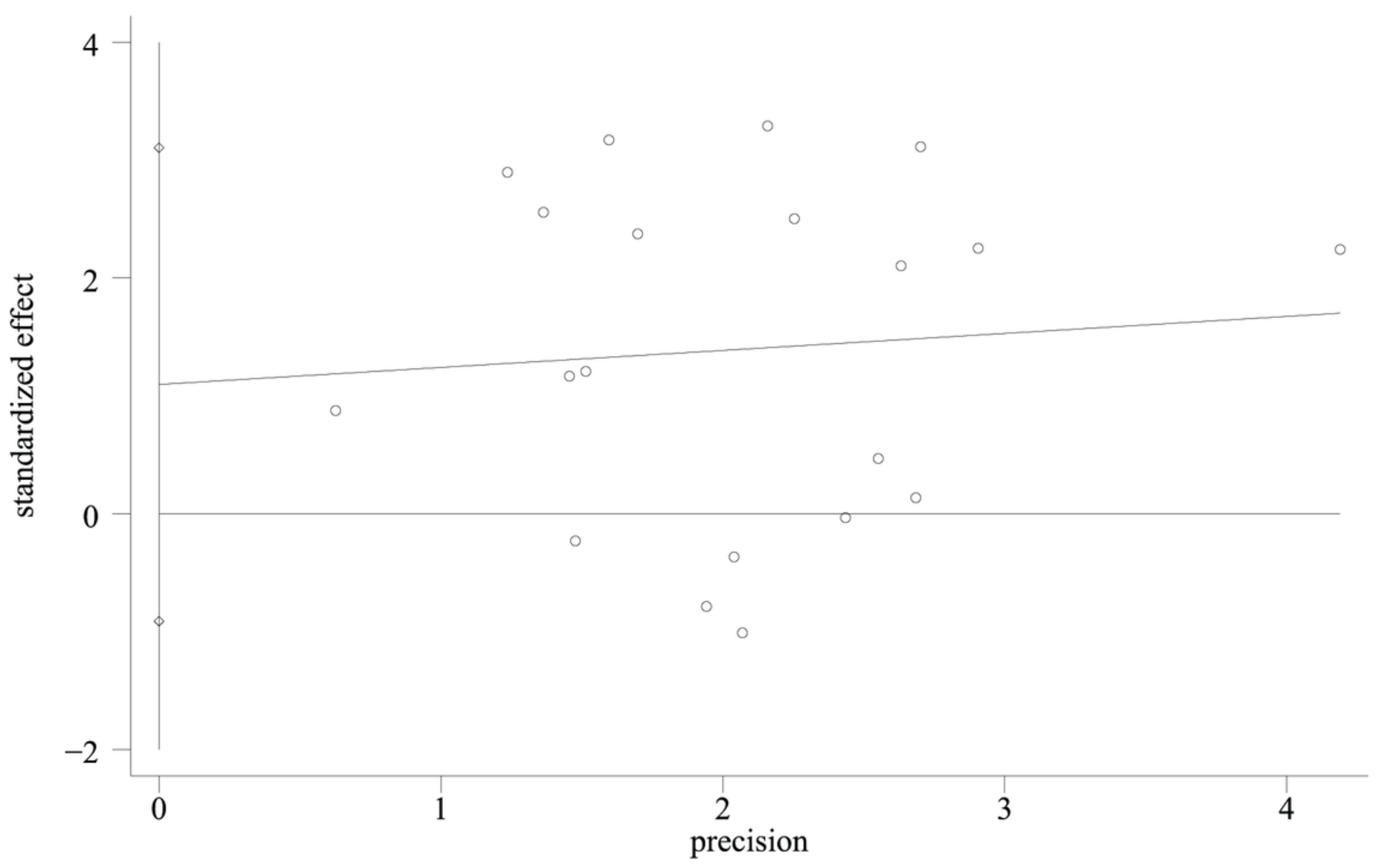

Figure 18

Egger's publication bias plot to evaluate the publication bias of overall complications.

\section{Supplementary Files}

This is a list of supplementary files associated with this preprint. Click to download.

- Electronicsearchstrategyoneachdatabase..docx

- Additionallnformation.docx 